\title{
ÁNFORAS VINARIAS EN EL ESTE DE LA HISPANIA CITERIOR EN ÉPOCA TARDORREPUBLICANA (SIGLO I A.C.): EPIGRAFÍA ANFÓRICA Y ORGANIZACIÓN DE LA PRODUCCIÓN
}

\author{
WINE AMPHORAE IN EASTERN HISPANIA CITERIOR IN LATE REPUBLICAN TIMES (Ith \\ CENTURY BC): AMPHORAE EPIGRAPHY AND ORGANIZATION OF PRODUCTION
}

\author{
RAMÓN JÁRREGA DOMÍNGUEZ*
}

\begin{abstract}
Resumen: El objetivo de este trabajo consiste en valorar las razones que llevaron a la producción de ánforas vinarias en la zona de la actual costa catalana en el siglo I a.C. (especialmente en su segunda mitad). Se plantea la relación de la colonización cesariana y del Segundo Triunvirato con la producción y difusión de las ánforas de la forma Tarraconense 1. Analizamos el papel que en su elaboración pudieron jugar los personajes mencionados en los sellos anfóricos, de origen itálico, que podrían haber sido inversores foráneos o inmigrantes de la colonización cesariana.

Palabras clave: Anforas vinarias, Hispania Citerior, época tardorrepublicana, Tarraconense 1, producción anfórica, epigrafía anfórica.
\end{abstract}

\section{INTRODUCCIÓN}

El objeto del presente estudio son las primeras producciones de ánforas de las formas Dressel 1 y Tarraconense 1 de los siglos II-I a.C. en la zona nordeste de la antigua Hispania Citerior o Tarraconensis, es decir, aproximadamente lo que hoy es la actual Cataluña. Nos centraremos en la tipología asociada a la cronología de las formas, así como en la interpretación de los sellos

* Institut Català d'Arqueologia Clàssica. Pza. de Rovellat sn, 43003 - Tarragona. Correo-e: rjarrega@icac.cat
Abstract: The aim of this study is to evaluate the reasons that led to the production of amphorae in the current Catalan coast in the first century BC (especially in the second half). We explore the relationship of the cesarean colonization and the Second Triumvirate with the production and diffusion of the amphorae of form Tarraconense 1. We analyze also the role that in its development could play the persons mentioned in the amphora stamps, of Italian origin, who may have been foreign investors or immigrants from the cesarean colonization.

Key-words: Amphorae for wine, Hispania Citerior, Late Republican period, Tarraconense 1 production of amphorae, epigraphy of amphorae.

anfóricos, a partir de lo cual intentaremos plantear las causas y la significación de estas producciones anfóricas en esta área concreta.

\section{PRIMERA FASE: EL INICIO DE LA PRODUCCIÓN. LA DRESSEL 1}

Las primeras ánforas vinarias indígenas detectadas en la zona son las imitaciones de las ánforas itálicas de la forma Dressel 1, si bien en el área costera del Maresme, al nordeste de Barcelona, se documentan 


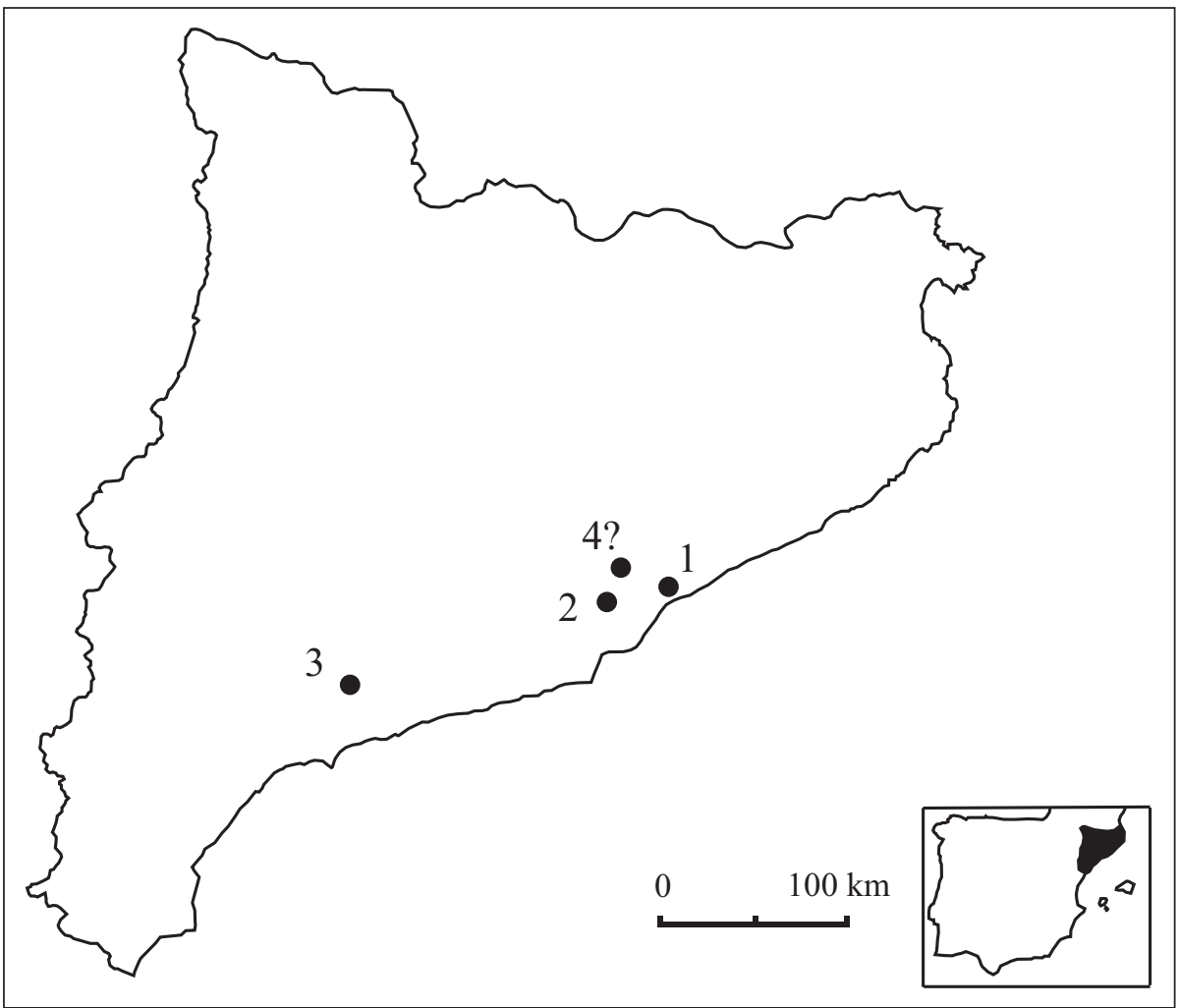

Figura 1. Distribución de los talleres que produjeron ánforas de la forma Dressel 1 del este de la Hispania Citerior. 1. Zona de Cabrera de Mar-poblado ibérico de Burriac.

2. La Salut (Sabadell).

3. El Vilar (Valls).

4. Mas Vendrell (Santa Eulàlia de Ronçana). Posible figlina.

algunas producciones autóctonas de ánforas de tipo greco-itálico, que pueden fecharse hacia la segunda mitad del siglo II a.C. (López y Martín 2008: 34). Estas imitaciones, especialmente del tipo Dressel $1 \mathrm{~B}$, no parecen haber tenido una geografía muy extensa (fig. 1); la producción principal se localiza en la zona del Maresme (costa central catalana), especialmente alrededor del poblado ibérico y del núcleo romano-republicano de Cabrera de Mar y Burriac (López y Martín 2008: 38-42). Otro punto se ha localizado en la zona del Alt Camp, en el interior del antiguo ager de Tarraco, cerca de Valls; se ha documentado un posible taller en el yacimiento de El Vilar (Valls), donde además de ánforas de tipo convencional se han identificado versiones en miniatura que no encuentran paralelos en otros lugares (López y Martín 2008: 37-38). Finalmente, se señala su posible producción en el taller de La Salut (Sabadell), en la actual comarca del Vallès Occidental (provincia de Barcelona) (Casas 1987).

La cronología de estas ánforas no es fácil de precisar, pues demasiadas veces se ha puesto de relieve su coexistencia en estratigrafías junto con las ánforas Tarraconense 1 e incluso la Pascual 1 y se ha hecho llegar su cronología hasta el cambio de Era (Comas 1998: 226; García y Gurri 1996-97: 415), sin tener en cuenta los factores de residualidad que probablemente expliquen mejor esta coexistencia. A grandes rasgos, podemos considerar que su producción se inicia a finales del siglo II o inicios del I a.C., alcanzando su máxima expansión en el segundo cuarto y mediados del siglo I a.C. (López y Martín 2008: 42). $\mathrm{Su}$ difusión aparece muy reducida, pues tan sólo se han documentado en reducidas cantidades en diversos yacimientos alrededor de Tarraco, estando todavía por valorar su posible presencia en el núcleo urbano de esta ciudad (Járrega y Abela 2001: 151), que debería haber sido el mercado natural de la producción del taller de El Vilar y su salida marítima; por ello, podemos suponer que estas producciones debieron ser los primeros intentos de comercialización de los vinos de esta zona de la Hispania Citerior, y que no debieron alcanzar una gran difusión. De todos modos, estas ánforas se han documentado en Mallorca y Menorca, así como algunos posibles ejemplares (de identificación insegura) en Burdeos o en el pecio de Cap-Béar 3, en el sur de Francia (López y Martín 2008: 43), que permiten pensar en una incipiente difusión exterior, aunque debió ser bastante limitada, no pudiendo competir todavía con los vinos itálicos contemporáneos. 
La epigrafía en relación con estas primeras ánforas "tarraconenses" es muy escasa. Se han documentado dos ejemplares de la forma Dressel 1 en la comarca del Alt Camp (Tarragona) y no lejos del posible centro productor de El Vilar mencionado anteriormente, que tienen marcas en las asas escritas en alfabeto ibérico (Carreté, Keay y Millett 1995: 81-82, figs. 5.14 y 5.15), Su transcripción, que parece ser NIO, no ha podido ser interpretada. Por lo tanto, cualquier hipótesis sobre la propiedad de la tierra y la gestión de las figlinae es tan válida como gratuita, pues estas inscripciones no nos pueden indicar, al no poder interpretarse, nada acerca de los propietarios ni de los agentes del proceso de producción. Es tan válido suponer que se trata de indígenas como de itálicos, pues si limitamos (como parece claro que debe hacerse) la epigrafía anfórica al mundo de la figlina es evidente que los trabajadores de la misma (que no necesariamente los propietarios) sean indígenas, y que en un momento en el que la escritura latina estaba todavía escasamente introducida en la zona estudiada escribiesen sus sellos en alfabeto ibérico.

No obstante, paralelamente (o en todo caso, poco más tarde) comenzaron a marcarse ánforas con textos latinos (fig. 2). En el borde de un ejemplar de la forma Dressel 1 A hallado en Mas Vendrell (Santa Eulàlia de Ronçana, Barcelona) en la comarca del Vallès Oriental, aparece un sello con el texto Q·E; al lado se aprecia un signo inciso que podría ser ibérico, que parece leerse "ke" o "ko" (Pera 1994). Probablemente la letra Q corresponde a un praenomen, con lo cual la E sería la inicial de un nomen, de identificación problemática, pues muy pocos nomina comenzaban con esta letra (Egnatius, Erucius?). Por otro lado, en los asentamientos ibéricos tardíos de Can Portell y Can Balençó (Argentona, Barcelona) en la comarca del Maresme, se hallaron dos fragmentos de borde con la marca Q.FABI en ambos (CODEX 1992: 167 y 170-171; CODEX 1995a: 45; CODEX 1995b: 64).

Evidentemente Fabius es un nomen de origen romano antiguo y no puede descartase que este Fabio pudiese ser un hispano romanizado (Olesti 1997 y 1998). Sin embargo, tampoco puede descartarse que se trate de un romano o itálico (Díaz Ariño 2008: 265), lo que nos parece más coherente en un período en el cual, si bien se documentan los primeros y escasos hábitats que responden a la tipología de la villa romana (Járrega 2000) persiste mayoritariamente una clara continuidad de los modos de vida ibéricos. Ello continuó así prácticamente hasta la época de Augusto, por lo que se hace difícil creer que el elemento indígena haya tenido

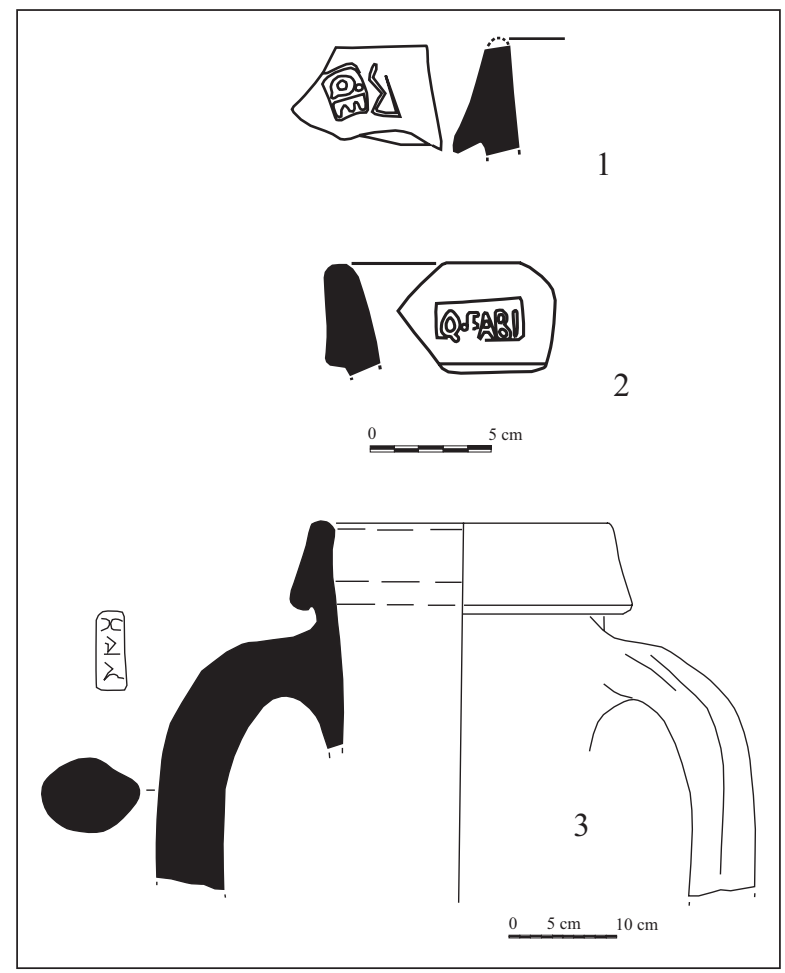

Figura 2. Sellos de ánforas de la forma Dressel 1 del este de la Hispania Citerior (fuentes: CODEX 1992; Carreté, Keay y Millett 1995; CODEX 1995a; CODEX 1995; Pera 1994; Berni y Miró 2013).

algún papel importante en la organización de la producción anfórica y vinaria; hay que tener en cuenta que, como argumenta Pena (1998: 305) quien se dedicase a este negocio debería tener un cierto capital y un conocimiento del mercado que a priori nos puede resultar algo extraño entre los indígenas, no así entre los itálicos que en aquellos momentos estaban desarrollando el comercio masivo de vinos de procedencia itálica, como se puede comprobar en toda la costa catalana (Nolla y Nieto 1989; Járrega y Abela 2001: 146-147).

En el caso, que nos parece más probable, de que el mencionado $Q$. Fabius sea de procedencia itálica resulta inútil intentar cualquier intento de identificación a través de las fuentes escritas y de los hallazgos epigráficos, pues se trata de nombres muy comunes. Eso sí, comunes entre la élite de Roma, a la que dieron abundantes cónsules desde los primeros tiempos de la República, por lo que podríamos pensar que los reflejados en las marcas anfóricas son miembros de esta élite, que debieron empezar a extender su influencia en Hispania en algún momento del siglo I a.C., adquiriendo algunos fundi. En tal caso, sería más lógico identificarlos como possesores que como negotiatores, por las razones 
expresadas más arriba. Ello podría contribuir a explicar la presencia, escasa pero significativa, de las primeras villae de época republicana (Járrega 2000).

\section{SEGUNDA FASE. LA PRIMERA ORGANIZACIÓN DE LA PRODUCCIÓN. LAS ÁNFORAS TARRACONENSE 1}

A esta fase corresponde el despegue real de la producción anfórica vinaria de esta zona, como se refleja en la multiplicación de sellos anfóricos, pero sobre todo en la difusión (menor que en las producciones posteriores, pero ya apreciable) de las ánforas características de este período, las denominadas Layetana 1 por Comas (Comas 1985; Comas y Casas 1989) y Tarraconense 1 por Nolla (Nolla 1987; Nolla y Solías 1988). La denominación Layetana 1 procede del hecho de haberse identificado inicialmente en la costa layetana (la zona central costera catalana, incluyendo las actuales ciudades de Barcelona, Badalona y Mataró); sin embargo, Nolla ha argumentado su posible producción en la zona de Ampurias, más al norte, por lo que la denominación de Layetana le parece poco adecuada, optando por la de Tarraconense que atribuyó Tchernia (1971) a esta zona y que ha hecho fortuna, si bien hay que señalar que en realidad en las cercanías de la antigua Tarraco no tenemos evidencia segura de la producción de estas ánforas, aunque se haya sugerido (López y Martín 2008: 50).

El ánfora que, para evitar duplicidades y aun siendo conscientes de que ninguna de las dos denominaciones es totalmente correcta, designaremos como Tarraconense 1 (que además, parece haber tenido mayor éxito en la bibliografía), que prefigura tipológicamente la posterior Pascual 1, es pequeña, de labio poco alto. $\mathrm{Su}$ inspiración tipológica se discute, si bien se han señalado como precedentes las ánforas apulas, concretamente las de Brindisi. Hay que tener en cuenta que las ánforas brindisinas, que tradicionalmente se habían considerado olearias (basándose en las referencias escritas sobre la abundancia y calidad del aceite de la zona), se ha planteado que en realidad puedan haber sido contenedores vinarios (Panella 1973, Manacorda 1990; Manacorda y Pallecchi 2012). En todo caso, la aparición de esta forma coincide en el tiempo con la de otras producciones similares de la zona bética localizadas en el valle del Guadalquivir, que conforman las denominadas ánforas "ovoides", que han comenzado a sistematizarse en los últimos años (García Vargas, de Almeida y González Cesteros 2011).
Long (1998) publicó unas ánforas halladas en un pecio localizado junto a Marsella que él mismo propuso llamar “Layetana 2". A. López y A. Martín (2008: 45-47) la denominan Tarraconense $1 \mathrm{C}$, que parece ser una evolución de perfil fusiforme de la Tarraconense 1 "clásica" (la Tarraconense 1 A de López y Martín), que tiene un perfil ovoide. Sin embargo, podrían ser algo más tardías, pues presentan la marca L·VOLTEIL en el cuello, algo que sólo aparece también en la marca M.LOREI (documentada en un ejemplar fragmentario), mientras que las otras marcas en Tarraconense 1 aparecen casi siempre en el labio. Por todo ello, hemos de considerar la Tarraconense $1 \mathrm{C}$ como una posible evolución fusiforme de la Tarraconense 1 clásica, o bien un ánfora distinta, con características físicas que la hacen parecer próxima a la Pascual 1.

Un problema en el cual nadie se había fijado hasta ahora, es que cuando no se dispone de ejemplares completos, es muy difícil (por no decir imposible) distinguir entre las diferentes variantes de la Tarraconense 1, que al ser la segunda una evolución tipológica de la primera, cabe suponer que también sea algo posterior.

\subsection{Cronología}

La cronología del ánfora Tarraconense 1 se ha situado grosso modo entre los años 40 y 30 a.C. (Comas 1985: 219), aunque se ha planteado una continuidad hasta el cambio de Era (Nolla 1987: 219; Nolla y Solías 1988: 138). En un silo hallado en Badalona la forma Tarraconense 1 aparece en un contexto con ánforas Dressel 1 "tarraconenses" y sin terra sigillata itálica ni ánfora Pascual 1, por lo que se ha datado hacia mediados del siglo I a.C. (Comas 1998: 221-222). La datación de este contexto ha sido considerada demasiado alta, y se ha sugerido que habría que rebajarla hacia el 20 a.C. (Beltrán Lloris 2008: 274-275), por la presencia de terra sigillata itálica (forma Conspectus 8.1.2) y cerámica de paredes finas (forma Mayet 14) datables en el último decenio antes de nuestra; sin embargo, no podemos descartar que otros materiales, como los que aquí nos ocupan, puedan ser algo más antiguos. Hay que tener en cuenta que no siempre los contextos reflejan la totalidad de materiales posibles, dependiendo de las cantidades que se hayan podido documentar; por ello, no es fácil saber si se trata de un contexto con materiales mayoritariamente anteriores y algunos más modernos, y en definitiva, si dicho contexto es utilizable para datar estos materiales.

En la misma Badalona se han hallado en contextos de hacia el año 40 a.C. varios ejemplares con las 
marcas Q·MEVI, C·MVCI, C·SERVILI y SEX·STA (Comas 1997: 15-19). Por otro lado, diversos hallazgos en Francia (Arles, Nimes, e incluso en Bretaña) se fechan entre los últimos decenios anteriores al cambio de Era y la época de Tiberio (López y Martín 2008: 53), lo que podría reforzar la datación baja que propone Beltrán. De todos modos, como veremos seguidamente, los hallazgos efectuados en pecios abonan una datación alta (López y Martín 2008: 53-54).

Los hallazgos submarinos en pecios, por su carácter de conjuntos cerrados, permiten en teoría una mejor aproximación a los aspectos cronológicos. En el pecio de Cap Béar III la forma Tarraconense 1 (con el sello $\mathrm{P} \cdot \mathrm{MEVI}$ ) se documenta en un contexto anterior al año 10 a.C., por la presencia de ánforas de la forma Dressel $1 \mathrm{~B}$, pero evidentemente esta datación ante quem no nos permite precisar la cronología concreta, que se ha propuesto situar hacia el 30 a.C. (Colls 1986: 210-213). El pecio de las islas Formigues, junto a Palamós (Gerona) tenía un cargamento de ánforas de la forma Tarraconense 1 (una de ellas con la marca L·VOLTEIL in planta pedis) acompañadas de cerámica campaniense B (formas Lamboglia 5 y 7 / Morel 2260 y 2270) y un vaso de cerámica de paredes finas de la forma Mayet 3 A (Foerster, Pascual y Barberà 1987). Asimismo, se señala una posible ánfora Pascual 1 falta del borde, lo que, teniendo en cuenta las diversas evoluciones de la forma Tarraconense 1, permite dudar de esta identificación. Este pecio se dataría, según López y Martín (2008: 53) hacia los años 40-30 a.C.

Finalmente, en el pecio de Cala Bona (Cadaqués, Gerona), situado como el anterior en la Costa Brava, se hallaron ánforas ovoides béticas, ánforas Tarraconense 1 (con los sellos L·FVL·LIC o L·FV·LIC, de lectura dudosa, y Q·MEVI), junto con lucernas de las formas Dressel 3 (datables entre los años 70/60 y 20/10 a.C.) y Ponsich $1 \mathrm{C}$ (con una datación más amplia, entre la segunda mitad del siglo II y el I a.C.). Todo ello, junto con la ausencia de la forma Pascual 1, lleva a López y Martín (2008: 54) a datar el conjunto hacia los años 50-30 a.C.

\section{2. Áreas de producción}

La producción de la forma Tarraconense 1 parece detectarse en las cercanías de la ciudad de Emporiae (Ampurias), si bien no se han localizado los talleres. Diversos ejemplares (al menos cinco) de la marca L.VENVLEI se han hallado en esta ciudad (Nolla 1974: 196-197), lo que indicaría que se produjeron en esta zona; por otro lado, se ha documentado al parecer su producción en los talleres de Fenals (Lloret de Mar), el Collet de Sant Antoni (Calonge) y Llafranc (Nolla 2008: 165-167 y 174; Tremoleda 2008: 118-199 y 121-122), todos ellos en la zona costera de la actual provincia de Gerona. También puede considerarse segura su producción en el taller de La Salut (Sabadell, Barcelona), en la comarca del Vallès Occidental, donde se han documentado bastantes ejemplares, algunos de ellos deformados (Casas 1987: 19-20); a esta figlina puede atribuirse el sello $\mathrm{M} \cdot \mathrm{CO}$, atribuido (creemos que erróneamente) a la forma Dressel 1.

Asimismo, se ha atribuido la producción de ánforas con el sello L·VOLTEIL al yacimiento de El Sot del Camp (Sant Vicenç de Montalt, Barcelona), en la comarca del Maresme (Revilla 1995: 262-263; Tremoleda 1998: 122). Sin embargo, hay que tener presente que en Baetulo (Badalona) se han detectado cinco ejemplares más o menos bien conservados de esta marca (Comas 1997: 17-18) por lo que no nos parece descartable que pueda haberse producido en las inmediaciones de esta ciudad. En la misma comarca se documentado la producción de ánforas de la forma Tarraconense 1 en Can Mateu (Cabrera de Mar), y quizás en Can Portell (Argentona) (CODEX 1992: 170-173; López y Martín 2008: 50). Asimismo, parece haberse producido también en Les Casetes (Mataró) y Horta Nova (Arenys), si bien se conocen muy pocos datos, basados en prospecciones superficiales (Revilla 1995: 259 y 261); al parecer, en el segundo se producían también ánforas de la forma Pascual 1. Se ha hallado un ejemplar, que publicamos aquí por primera vez, en El Roser o El Mujal (Calella, Barcelona), con el sello L·FVLVI (fig. 5), taller donde se produjeron en abundancia ánforas de las formas Pascual $1 \mathrm{y}$ Dressel 2-4; sin embargo, se trata de un único ejemplar hallado sin contexto estratigráfico, por lo que su posible atribución a este taller presenta dudas.

Se ha señalado también su posible producción en la zona oriental del territorio de Tarraco, en El Vilarenc (Calafell), y Tomoví (Albinyana - Santa Oliva) (Revilla 1994: 116; Martín y Prevosti 2003: 235-236; López y Martín 2008: 50) aunque no hay evidencia directa (como fallos de cocción) y podría tratarse de importaciones layetanas.

Por lo tanto, todo apunta a que se trata de una producción focalizada en la zona de la Costa Brava, el Vallès y el Maresme (fig. 3), es decir, en el área central y septentrional de la costa catalana (y quizás también en el área oriental del ager Tarraconensis) y su "hinterland" interior, si bien no se han identificado en cantidades apreciables ni se han documentado fallos de cocción en los pocos ejemplares hallados en los talleres productores. 


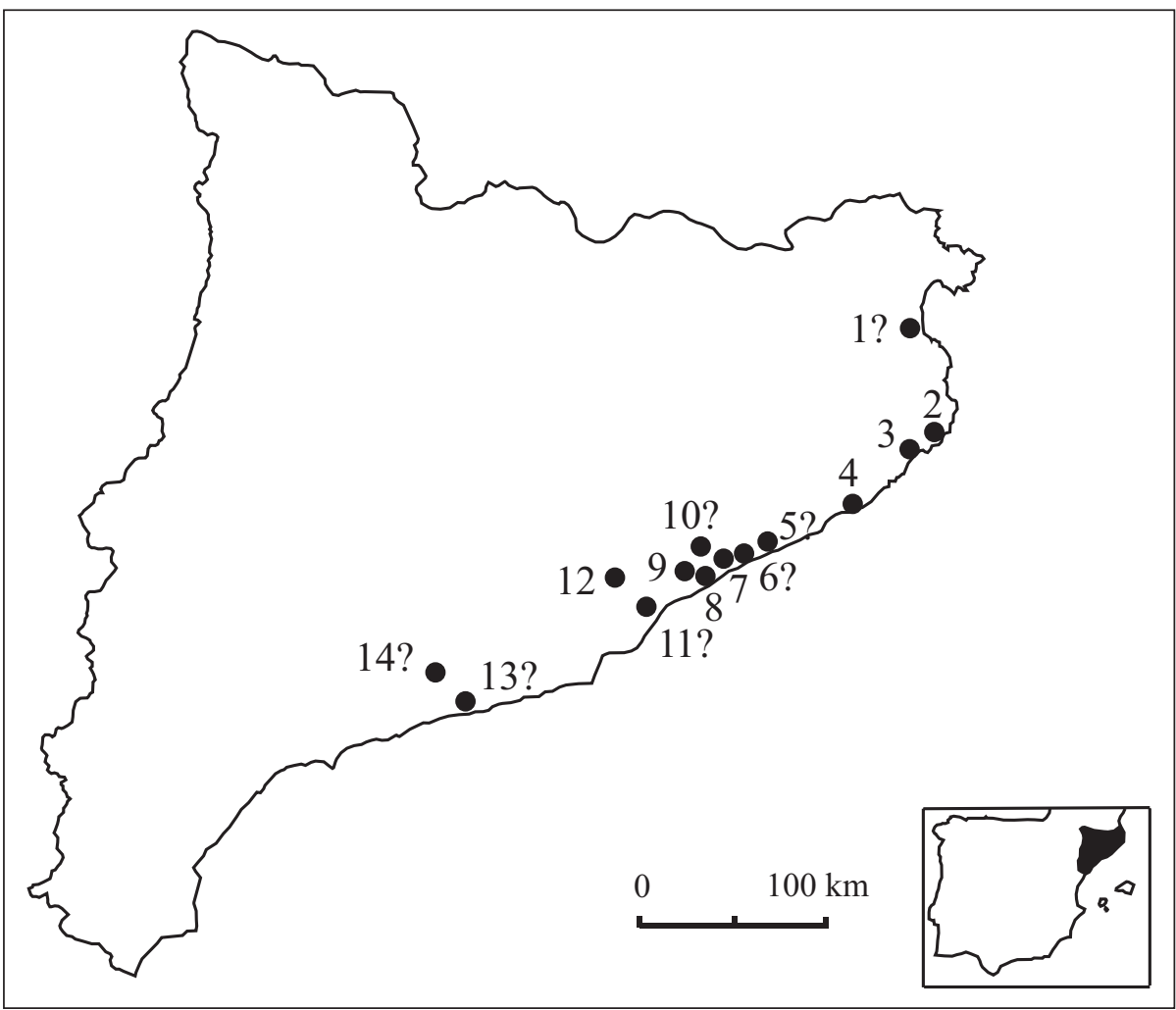

Figura 3. Distribución de los talleres que produjeron ánforas de la forma Tarraconense 1. 1. Zona de Ampurias. 2. Llafranc. 3. Collet de Sant Antoni (Calonge).

4. Fenals (Lloret de Mar). 5. El Roser o el Mujal (Calella). 6. Horta Nova (Arenys de Mar).

7. El Sot del Camp (Sant Vicenç de Montalt).

8. Les Casetes (Mataró). 9. Can Mateu (Cabrera de Mar). 10. Can Portell (Argentona). 11. Baetulo (Badalona). 12. La Salut (Sabadell). 13. El Vilarenc (Calafell). 14. Tomoví (AlbinyanaSanta Oliva).

\subsection{Epigrafía}

Los sellos de las ánforas de la forma Tarraconense 1 (fig. 4) se sitúan principalmente en el labio y en algunos casos en el cuello de las ánforas, y excepcionalmente en la panza. Son bien visibles, y presentan textos bien desarrollados que corresponden a un nomen en nominativo, siempre con la inicial del praenomen delante. El nomen puede desarrollarse completo o abreviado. Los estudios de Pena y Barreda (Pena y Barreda 1997; Pena 1998) creemos que han demostrado que se trata de nombres de itálicos poco o nada conocidos en la epigrafía lapidaria de la zona productora. Los nomina documentados más recientemente, como en el caso de $P$. Heidius, no hacen más que reforzar estas conclusiones.

Los nombres documentados (una decena escasa) bien estudiados por Pena y Barreda (Pena y Barreda 1997; Pena 1998; veáse también Berni y Miró 2013: 6667), son L·FVL·LIC, Q·MEVI, C·MVCI, SEX·STATI, $\mathrm{L} \cdot$ VENVLEI, L·VOLTEIL, y C.IVN, ya publicados por Miró; además de M·LOREI.. /.. ARCEL·AVC de Ampurias (AQUILUÉ et al. 1984: 154 y fig. 87, nº 12) y C.SERVILI de Badalona (Comas 1997). Estas marcas (excepto C·SERVILI) aparecen también en el catálogo de Pascual (1991) de los sellos de las ánforas denominadas tarraconenses. A ellos hay que añadir cuatro marcas más, MANTO (que, a pesar de la inexistente apariencia del punto en los dibujos publicados, habría que leer M·ANTO), que se documenta también en la forma Pascual 1, de la que se conoce un ejemplar hallado en la antigua Blandae (Blanes), en la colina de Els Padrets de Blanes, en la comarca del Maresme (Barcelona) y que, pese a estar publicado desde hace años (Vilà et al. 1978: 231 y 232, fig. 8.90) ha pasado extrañamente desapercibido a todos los investigadores que se han ocupado de este tema.

Finalmente, hay que reseñar una marca P.HEID, procedente de Vinyes de Can Prat (Collsabadell, Llinars del Vallès, Barcelona) hasta hace poco inédita (Berni, Clariana y Járrega 2012), así como otras dos fragmentarias y desgraciadamente ilegibles (y de las que, por tanto, no nos ocuparemos aquí), una en el labio de una posible Tarraconense 1 de la que sólo se aprecia la letra $\mathrm{R}$ al final del texto, hallada en el Cours du Chapeau Rouge, en Burdeos (Berthault 2009: fig. 28, M26), y otra procedente del castillo de Miravet (provincia de Tarragona) junto al río Ebro, donde sólo se puede leer LA... en texto retrógrado, por primera vez documentado en Tarraconense 1 (Berni y Járrega 2012). Hay que añadir una marca $\mathrm{M} \cdot \mathrm{CO}$ probablemente referente a un 
Marcus Cornelius, que había sido erróneamente identificada como una Dressel 1, ya que en el yacimiento de La Salut (Sabadell, Barcelona) se ha hallado un fragmento de borde que, aunque se ha atribuido a la forma Dressel 1 B, parece corresponder en realidad a la Tarraconense 1, pues el perfil del labio es idéntico al de dos ejemplares de Tarraconense 1 de identificación segura que se publican adjuntos (Casas 1987: 17, fig. 3).

Los nombres que pueden leerse muy claramente a partir de las marcas corresponden a Marcus Antonius, Publius Heidius, Caius Iunius, Marcus Loreius, Quintus Mevius, Caius Mucius, Caius Servilius, Sextus Statius, Lucius Venuleius y Lucius Volteilius (o Voltilius), así como posiblemente Marcus Cornelius. Sólo en un caso, el de M·LOREI.. /.. ARCEL·AVC (esta segunda parte de interpretación dudosa) se documentan dos nombres en la misma ánfora. En el caso de L FVL $\cdot \mathrm{LIC}$ es posible que se trate de unos tria nomina; éste sería el único caso conocido hasta ahora en ánforas de la forma Tarraconense 1.

Sobre la procedencia geográfica de estos nomina, resumimos seguidamente los resultados de los estudios de Pena y Barreda (Pena y Barreda 1997; Pena 1998), además de añadir los documentados posteriormente (M. Antonius, P. Heidius y el probable M. Cornelius):

- M. Antonius. Se conoce un solo ejemplar hallado en Blanes (Vilà et alii 1978: 231), si bien existen ejemplares de la forma Pascual 1 con marcas similares, como se comentará más adelante. El nomen Antonius es relativamente abundante en la epigrafía latina, aunque no excesivamente; en la base de datos de Eagle se han documentado 203 epígrafes de un total de 45536, de los cuales 94 corresponden a personajes denominados Marcus Antonius. Sin embargo, la mayoría de estas inscripciones son de época imperial. El personaje más conocido de este nombre es evidentemente el famoso triunviro Marco Antonio (más o menos contemporáneo de la marca en Tarraconense 1), pero existen otros muchos homónimos más o menos contemporáneos en Italia (véase Eagle, EDR005005, EDR005368 y EDR017350.

- M. Co[(rnelius?]. Un ejemplar hallado en La Salut (Sabadell, provincia de Barcelona) presenta un sello de lectura dudosa, M·COR. o M.COS (Casas 1987: 18, lám. 2.1 y 19, fig. 2.2); en el primer caso puede desarrollarse sin duda como M. Cornelius, mientras que la segunda posibilidad es posible que pueda leerse M. Cossius o Cossutius. Este ejemplar se ha atribuido en la publicación original a la forma Dressel $1 \mathrm{~B}$, pero parece corresponder en realidad

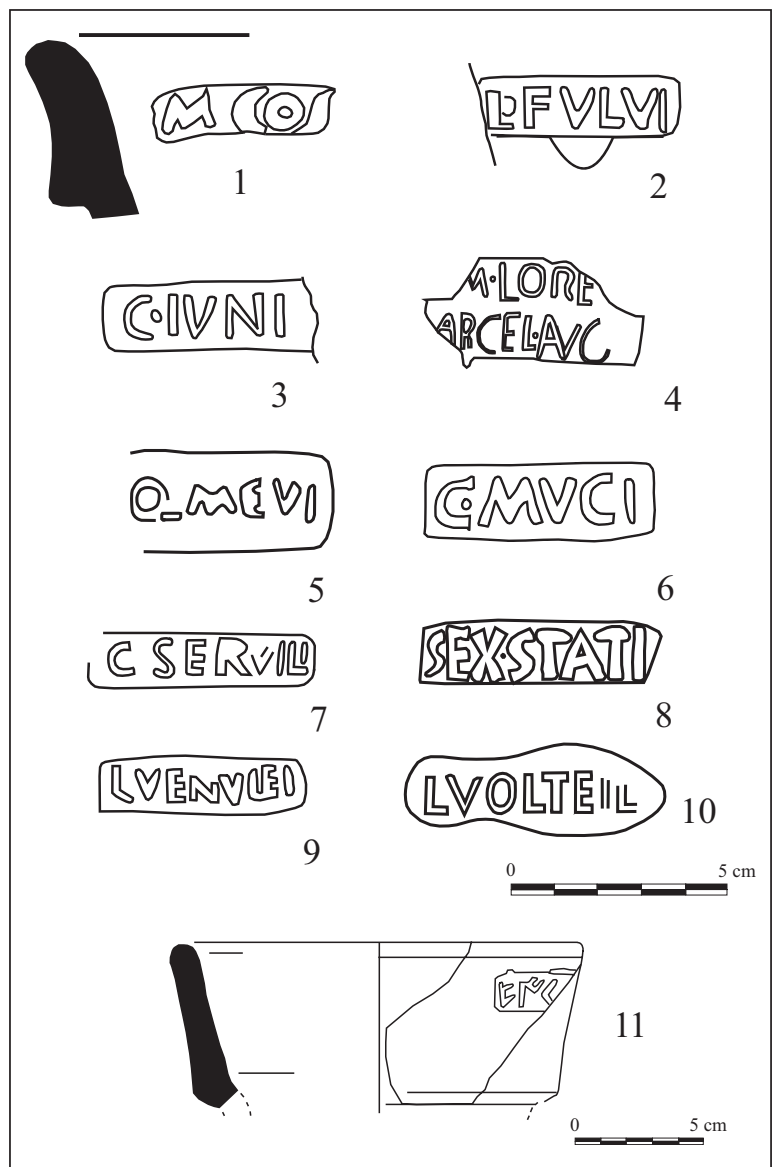

Figura 4. Sellos de ánforas de la forma Tarraconense 1 (fuentes: Almagro 1952; Casas 1987; Comas 1985; Pena 1998; Panosa, M.I. 2002; Berni y Miró 2013).

a la Tarraconense 1, pues el perfil del labio es idéntico al de dos ejemplares de Tarraconense 1 de identificación segura que se publican adjuntos. La gens Cornelia es una de las grandes familias patricias de Roma; no obstante, existen también ramas plebeyas, como los Lucii Cornelii Balbi padre e hijo, el primero de los cuales recibió la ciudadanía romana a mediados del siglo I a.C. El praenomen Marcus es poco habitual entre los Cornelii. Evidentemente, es imposible identificar el personaje mencionado en la marca anfórica, especialmente cuando ni tan sólo estamos seguros de la lectura del cognomen.

- L. Fulvius. Existen dos variantes, L·FVLVI (en el borde), de Ampurias (Almagro 1952: núm. 213; Pena 1988: 314 y 317; 318, fig. 1.3) y L FVL $\cdot$ LIC (en el hombro) hallada en el pecio de Cala Bona (Cadaqués), en la Costa Brava (Nieto y Raurich 1998: 114 y 132, fig. 2; Pena 1998: 314). En este último 


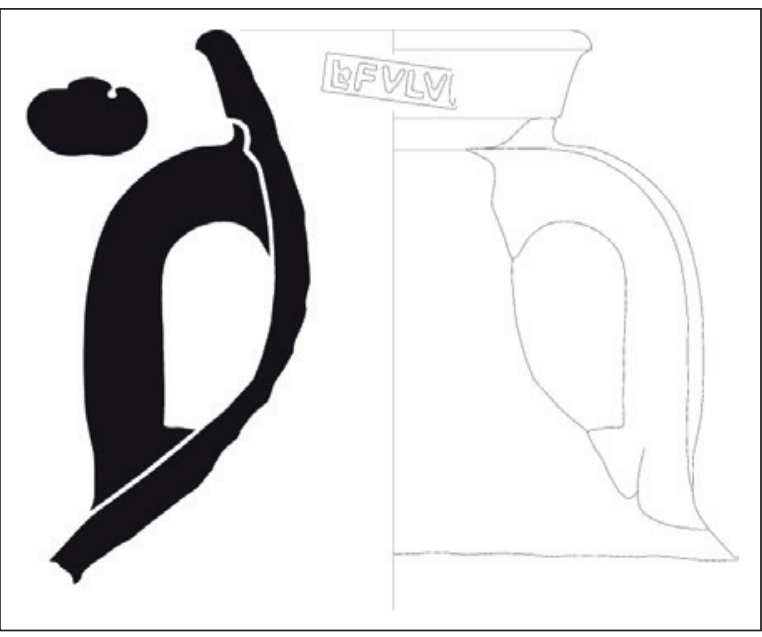

Figura 5. Fragmento de ánfora de la forma Tarraconense 1, con el sello L·FVLVI, hallado en el yacimiento de El Roser o El Mujal (Calella, Barcelona) (dibujo: Albert Martín).

caso al parecer nos encontramos con la presencia de unos tria nomina, que podemos desarrollar probablemente como Lucius Fulvius Licinianus, lo cual es prácticamente insólito en el caso de las ánforas Tarraconense 1. Existen en la forma Pascual 1 dos marcas, CN.FVL·SEC (que se refiere probablemente a un Cnaeus Fulvius Secundus) y FVL.PHIL (que corresponde al parecer a un Fulvius Phileros) (Pascual 1991: 50). Callender (Roman Amphorae, Oxford, 1965: núm. 1097) cita una marca de dolium de Pompeya donde se lee PHILEROS M. FVLVI SER (CIL X 8047,15); es muy posible que en ambos casos se trate de una doble homonimia, pero no podemos descartar que el Phileros de Pompeya fuese manumitido por Fulvius y acabase trabajando en una figlina de la costa catalana.

Asímismo, se conoce una marca $\mathrm{L} \cdot \mathrm{FVL} \cdot \mathrm{HERO}$ en Dressel 7-11 producida muy probablemente en el taller del Mas d'Aragó, en Cervera del Maestrazgo (Castellón) (Fernández Izquierdo 2006: 285, fig. 15 que no sabemos si tienen relación alguna con el Lucius Fulvius mencionado en las ánforas Tarraconense 1. La gens Fulvia, de origen plebeyo y originaria de Tusculum, en el Lacio, generó un cognomen muy extendido, por lo que resulta imposible cualquier intento de identificación de este personaje. (Fig, 5)

- P. Heidius. Conocemos solamente un ejemplar, hallado en el yacimiento de Vinyes de Can Prat (Collsabadell, Llinars del Vallès, Barcelona) (fig. 6). El texto está fragmentado, leyéndose claramente
P.HEID, por lo que no sabemos si falta o no una letra, en cuyo caso podría leerse P·HEID[I]. Es un nomen rarísimo, del que se conocen tan sólo ocho inscripciones halladas en el centro y el sur de Italia (Campania), y en tres casos en el norte (Liguria y Emilia-Romagna). Se trata de inscripciones procedentes de Caraglio (Liguria), Bolonia (Emilia-Romagna), Santo Prisco (Caserta, en la Campania), y Sassoferrato, Acqualagna y Fossombrone, los tres en Umbria. Se fechan todas en el Alto Imperio, salvo quizás la de Caserta, que podría ser del siglo I a.C. (CIL 11, 05962, 05977, 06144 y 06838, CIL 19, 3783 (1) = CIL 001 (2 ed.), 0686; Eagle, EDR010180, EDR016187 = CIL 11, 05755 , EDR071657).

En ningún caso el praenomen es Publius, como en la marca anfórica, sinó Manius, Marcus y especialmente Lucius. El hecho de que cuatro de las ocho inscripciones procedan de Umbria, una de Sentinum (Sassoferrato), dos de ellas de Pitinum Mergens (Acqualagna) y otra de Forum Sempronii (Fossombrone) permiten suponer que la gens Heidia debía tener su origo en una zona muy localizada del sector oriental de la Umbria, en un área que podríamos definir dentro de un triángulo ideal entre Gubbio, Pesaro y Ancona, correspondiente a las actuales provincias de Pesaro-Urbino y Ancona. La inscripción de Sentinum hace referencia a dos Lucii Heidii (quizás padre e hijo) que fueron al parecer quattuorvir y aedilis; una de las inscripciones de $P i$ tinum Mergens, aunque está fragmentada, permite suponer que cierto Lucius Heidius fue quattuorviro o duumviro quinquenal en su ciudad. Por ello, podemos concluir que algunos de los Heidii llegaron en algún momento del Alto Imperio al "status" de magistrado municipal. Es muy posible que nuestro Publius Heidius formase parte de una rama de la familia que se dedicó a inversiones en Hispania, no sabemos si con mucha fortuna, dada la escasa repercusión de este nomen tanto aquí como en Italia.

- C. Iunius. Se conocen dos ejemplares sobre el borde de ánforas Tarraconense 1 de procedencia submarina, halladas una en la costa entre Mataró y Llavaneres (Barcelona) (Pascual 1981: fig. 13.4; Pascual 1991: 47, núm. 53.1) y la otra en Port-la-Nautique, el antiguo puerto de Narbona (ANTEAS 1993: 42, núm. 163). En el primer ejemplar el texto, según Pascual, es CIVN, mientras que en el caso de Narbona es C.IVNI Los Iunii son una familia romana de origen plebeyo con abundantes ramificaciones, de las que sólo unos pocos aparecen sin cognomen. 
El praenomen Caius es poco abundante, pero conocemos dos personajes, padre e hijo, contemporáneos de Cicerón (Cic., Pro Cluentio, 1, 20, 27, 29, 33 y 49), el primero de los cuales era uno de los jueces en el caso incoado por corrupción a Opiánico. También conocemos un C. Iunius Silanus, cónsul en el año 10 d.C., que fue acusado de malversación y traición (Tac., Ann., 3.66-67). Naturalmente, no estamos en condiciones de identificar el personaje mencionado en el sello anfórico que nos ocupa. Sin ir más lejos, podemos traer a colación el nombre de un ceramista que produjo lucernas en la bahía de Cádiz, Caius Iunius Dracus (Corzo 1982), que muy probablemente no tenía nada que ver con los Caii Iunii mencionados más arriba.

- M. Loreius. Se conoce un ejemplar de procedencia desconocida depositado en una colección particular de Cadaqués, con la marca M.LOREI en el cuello (Pena 1998: 208 y 317). Este nomen es el único que aparece en una marca asociada a otra, que al parecer puede leerse ARCELAVOS, documentada en dos ejemplares, hallados respectivamente en el pecio Mateille C en Gruissan, cerca de Narbona (Solier 1981: 232, fig. 94) y en el foro romano de Ampurias (Aquilué et al. 1984: 154-155 y 171, fig. 87.13; Pena 1998: 308 y fig. 1.1); podemos suponer que el segundo nombre, de interpretación dudosa, corresponde a un esclavo o liberto asociado al propietario, al igual que se constata en la epigrafía suditálica de época tardorrepublicana (Desy 1989) y como se comprobará en la epigrafía layetana y tarraconense posterior. El nomen podría ser de origen osco, según Gabba (1973; cf. Pena 1995: 309) aunque ello no es seguro. Se conocen diversos Loreii en Pompeya, de los que es de destacar un M. Loreius que fue IIIIvir i IIvir en época republicana (CIL I/2, 1629-1630 = CIL X 937 y 938); el nomen aparece en inscripciones de época imperial en Roma, Ostia, Verona, Mantua y Aquileia. En Galia se documenta también en Narbona (CIL XII 4731) y Glanum (AEp. 1946: núm. 153). En Hispania tenemos documentado un M. Loreius en Ampurias, un L. Loreius en la zona de Lisboa y una Loreia en Vega de Medellín (Cáceres) (Pena 1998: 308).

El hecho de que la marca se documente en el cuello de un ejemplar fragmentario, ubicación que se documenta también en el caso de la marca L·VOLTEIL que aparece en las ánforas fusiformes denominadas Layetana 2 por Long y Tarraconense $1 \mathrm{C}$ por A. López y A. Martín (mencionadas anteriormente) podría hacer pensar que las ánforas

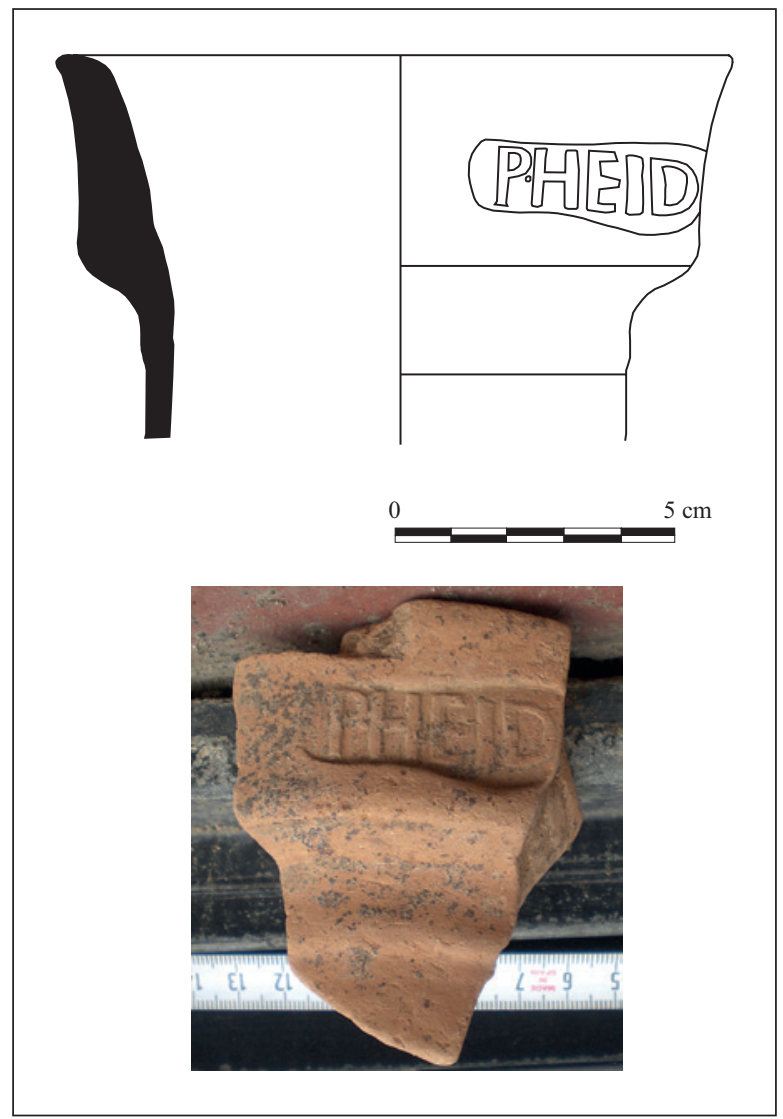

Figura 6. Fragmento de ánfora de la forma Tarraconense 1, con el sello P-HEID, hallado en el yacimiento de Vinyes de Can Prat (Collsabadell, Llinars del Vallès, Barcelona) (fuente: Berni, Clariana y Járrega 2012).

con la marca de $M$. Loreius no correspondan exactamente a la Tarraconense 1 clásica, pudiendo quizá ser algo posteriores. Desgraciadamente, el ejemplar ampuritano se halló en un contexto revuelto que no permite acotar su datación, y el de Cadaqués no tiene contexto alguno conocido.

- P. Mevius y Q, Mevius. Es interesante constatar que tenemos sellos que hacen evidentemente referencia al menos a dos personajes distintos, como consta por la indicación de los praenomina (Publius y Quintus), aunque el primero se ha documentado en un único ejemplar del pecio de Cap Béar III (Colls 1986). En cambio, la versión Q·MEVI es una de las más abundantes, documentándose en Badalona, donde se han hallado al menos cinco ejemplares, uno de los cuales, hallado en la calle de Pujol, tiene una datación estratigráfica de hacia el año 40 a.C. (Comas 1997: 17-18, núm. 6, 7 y 8). Se conoce un ejemplar de Ampurias (Almagro 1952: núm. 210; 
Nolla 1987: 221, fig. 2.1 y 222, núm. 2; Pascual 1997: 124, núm. 193.3) y otro de Ma Maison (Saintes), en un nivel arqueológico de época augústea precoz (Lauranceau 1988: 271 y 272 fig. 8.69; Carre et al. 1995: núm. 295). La marca MEVI, sin la inicial del praenomen, se documenta en un ejemplar completo de procedencia submarina en el litoral de Lloret de Mar (Vilà 1996), y también en ánforas de la forma Pascual 1 en Badalona, el Castell (Palamós), Ampurias, Port-la-Nautique (Narbona), y en tipos indeterminados en El Morè (Sant Pol de Mar) y Ruscino (Castell Rosselló) (véase referencias en la página web del CEIPAC). La marca MEVI se documenta también en Tarragona, en un cuello de posible forma Oberaden 74 (González y Járrega 2011). En todo caso, parece bastante claro que existieron diversos Mevii, probablemente de la misma familia, implicados en el proceso productivo de las ánforas vinarias en la zona catalana en los decenios inmediatos al cambio de Era. El nomen Mevius es probablemente de origen osco. Abunda en el sur del Lacio y en Campania, en ciudades como Formia, Puteoli y Pompeya; en época imperial aparece en Nápoles, Miseno, Cassino, Fabrateria Nova, Sepino, Histonium, Alba Fucens, Telesia, etc.

- En la base de datos Eagle el nomen no es abundante, figuran tan sólo 10 Mevii sobre un total de 45536 inscripciones recogidas. Asimismo, en Roma tenemos documentado un L. Mevius en una inscripción de la segunda mitad del siglo I a.C. (Pena y Barreda 1997: 307). En Narbona se conoce un M. Mevius (CIL XII 4991). En relación con Hispania este nomen aparece en una inscripción en lápida hallada en las fuentes del Tajo (CIL II 3618), además de en una marca de tégula de Mallorca (quizás de Pollentia), en un lingote de plomo hallado en la costa de esta isla, así como en un titulus pictus de una ánfora bética del Castro Pretorio y en otro de una Dressel 12 bética de Saint-Romain-en-Gal (datada entre 15 a.C. y 5 d.C.).

- C. Mucius. Según Comas (1997: 15) la marca $\mathrm{C} \cdot \mathrm{MVCI}$ se documenta en Baetulo (Badalona) en un contexto fechado hacia el año 40 a.C. Mucius es un nomen romano, documentado tempranamente por el conocido episodio de Mucius Scaevola durante la guerra de Porsenna en el siglo VI a.C. Con la familia senatorial de los Mucii Scaevolae, aparentemente descendiente del mencionado personaje, propone Pena (1998: 312) relacionar este sello, aunque la verdad es que ello resulta muy arriesgado. Sin embargo, existen muchas ramas plebeyas de esta familia (Donne 1870: 1117). La identificación del personaje es imposible, más aún cuando no se indica la inicial del praenomen. De todos modos, es interesante tener en cuenta que es rarísimo en la epigrafía hispánica.

Pena (1998: 313) menciona algunos Mucii con el praenomen Caius más o menos contemporáneos, documentados en inscripciones de Roma, Cerdeña y la Sabina, como por ejemplo, un $C$. Scaevola que fue uno de los XVviri sacris faciundis mencionados en el acta de los Ludi Saeculares del 17 a.C. (CIL VI 32323 = Dessau 5050). Pena propone relacionarlo con un C. MVCIVS C.F. / SCAEV ... / ...STA DE SVA PEC FEC mencionado en una inscripción de Cerdeña (CIL X 7543). Además de este (o estos) personajes, existen otros: C.MVCIVS C.F.Q.N. SCAEVO... de Foruli (entre Amiternum y Rieti) (CIL IX 4414), C. MVC... / CV... del ager de Amiternum (CIL IX 4444) y C.MVCIVS C.L. MELANTHUS, de Aquae Cutiliae (CIL IX 4670), Sin duda Melanthus sería un liberto, a juzgar por el cognomen. Por ello, se ha sugerido que estos personajes tenían propiedades en la Sabina (Comas 1997: 15; Pena 1998: 313). Obviamente, es imposible determinar cualquier relación con el Caius Mucius de la marca anfórica, pero en todo caso se demuestra que no es raro documentar Mucii con el praenomen Caius en época más o menos contemporánea de dicha marca.

- C. Servilius. En Baetulo (Badalona) se ha documentado un borde de ánfora Tarraconense 1 con el se1lo C.SERVILI, en un contexto datado hacia 40 a.C. (Comas 1997: 16). Los Servilii eran una gens de origen patricio, pero en época tardorrepublicana había también plebeyos con este nomen. Obviamente, el personaje del sello es inidentificable; Gaius Servilius Casca es el nombre de uno de los asesinos de César, pero no podemos establecer ningún tipo de relación con él, ni tan sólo hipotética.

- Sex. Statius: éste es un nomen (y también un cognomen) de origen osco, muy abundantemente documentado en la epigrafía latina. Pena cita como ejemplo significativo un Sex. Staativs Sex. $f$. de Amiternum (CIL I/2 1845 = IX 4642), en Italia. En Roma aparecen también dos Sex. Statii padre e hijo, de la primera mitad del siglo I a.C. En Narbona se conoce un liberto llamado también Sex. Statius, liberto de Sextus, datable probablemente en época de Augusto (Pena 1998: 310-311). Inicialmente se conocían solamente tres ejemplares con el texto fragmentario, uno de ellos de Ampurias (Almagro 1952: 
núm. 227; Nolla 1987: 221-222, núm. 4, 18-19 y fig. 2.3) y los otros dos de Badalona (Comas 1997: núms. 9 y 10), por lo que su lectura resultaba dudosa. Sin embargo, un ejemplar con el texto completo SEX-STATI (Panosa 2002: 34 y 64-66, foto 22), hallado en el interior de un silo en Montmeló (Vallès Oriental, Barcelona) ha permitido documentar con seguridad la identificación con Statius, como había propuesto Pena (1998: 310-311).

- L. Venuleius: el sufijo - eius es corriente en la zona centroitálica; no existen evidencias sobre la procedencia concreta de la gens Venuleia, aunque se ha sugerido que podrían proceder de la ciudad de $\mathrm{Co}$ pia, fundada sobre la antigua Thurii, en Calabria. En Italia este nomen aparece sólo en Pompeya y Herculano, así como en Roma y Pisa, aunque en esta última parece ser que los Venuleii se establecieron allí después de la deductio colonial augústea (Pena y Barreda 1997: 59 y 64). El nomen en Hispania aparece sólo en Valentia, tanto con la forma $\mathrm{Ve}$ nuleius como Vinuleius y en Carthago Nova (Pena y Barreda 1997: 56).

En Valentia aparece en dos inscripciones, una que menciona a L. Venuleius [---] Venul[eius Cas]sianus y Venuleia [---], y otra referente a $L$. Vinul(eius) Hesper, y una posible Vinuleia Primitiva (Corell y Gómez 2009: 156-158, núms. 85 y 86). Ambas inscripciones se datan en el siglo II d.C. Llama la atención el hecho de que los dos praenomina que se conservan sean Lucius; las formas Venuleius / Vinuleius evidentemente son variantes del mismo nomen. Es posible, por tanto, que exista una remota relación entre estos Venuleii y el que se menciona en los sellos anfóricos, pero existe una distancia de 200 años entre ellos. Llama la atención que este nomen aparezca precisamente en dos núcleos urbanos con presencia de itálicos desde el siglo II a.C. La producción de las ánforas con esta marca posiblemente se situó en las inmediaciones de Ampurias (Nolla 1974: 196-197).

- L. Volteilius / Voltilius. La forma presente en la epigrafía anfórica es Volteilius, aunque en la epigrafía lapidaria este nomen aparece también bajo la forma Voltilius. Pena y Barreda (Pena y Barreda 1997: 68) suponen que sea un nomen de origen samnita, por su similitud con el nombre de la tribu Voltinia, que fue atribuida después de la guerra social a los samnitas. En Italia el nomen Voltilius se documenta en Sora (Lacio meridional, en el límite con el Samnio) y en Roma. Fuera de Italia donde más abunda es en Narbo, donde se conocen nueve inscripciones con este nomen (Pena y Barreda 1997: 68-70). En Hispania solo se conoce un posible Volteilius o Voltilius en una inscripción de Ampurias, aunque el nombre está fragmentado (Fabre, Mayer y Rodà 1991: 51); recordemos que se ha sugerido que las ánforas con esta marca procedían precisamente de las inmediaciones de Ampurias. No existe ninguna mención literaria de nadie con este nomen. Cabe recordar que un sello de L·VOLTEIL in planta pedis ha sido documentado en el pecio de islas Formigues, junto a Palamós (Gerona), datable hacia los años 40-30 a.C. (López Martín 2008: 53), lo que confirma que éste sello corresponde claramente a la primera fase de la producción del ánfora Tarraconense 1. Esta marca se documenta también abundantemente, sobre todo con el formato in planta pedis, en ánforas de la forma Pascual 1, con una amplia difusión (Miró 1988a: 221; Comas 1997: 16). Por ello, esta marca es prácticamente el único caso (junto con el de MEVI) en el que tenemos documentada una continuidad entre las ánforas Tarraconense 1 y Pascual 1, que debe indicar una dilatada intervención del personaje mencionado o incluso una continuidad familiar.

Podemos añadir un sello que, sin seguridad, podríamos atribuir a la forma Tarraconense 1. La lectura es insegura, SEI o SEL, y probablemente está incompleta; obviamente, no es posible interpretarla. Corresponde a un borde de ánfora hallado en el Cours du Chapeau Rouge, en Burdeos (Francia). Aunque se ha publicado como una Dressel 1 B (Berthault 2009: fig.28, M5), viendo el dibujo de la pieza salta a la vista que éste es defectuoso, por lo que no es descartable que se trate de una Tarraconense 1 en lugar de una Dressel 1 B. En cualquier caso, este sello, por su imposibilidad de identificación, poco aporta a la temática que aquí estamos tratando.

\subsection{Difusión exterior}

La difusión de las ánforas de la forma Tarraconense 1 está ya mucho más extendida que en el caso de las Dressel 1 "tarraconenses", habiéndose documentado a lo largo de las rutas del Ródano hasta Bibracte y Bretaña, y del Garona (con origen en el puerto de Narbo) hasta Burdeos, así como, en Hispania, hasta Zaragoza y Termantia remontando el Ebro, al norte de la Comunidad Valenciana y en diversos yacimientos de Mallorca y Menorca (López y Martín 2008: 54; 
Beltrán Lloris 2008: 273-274). Esta difusión se puede seguir también gracias a la distribución de los sellos, que básicamente se documentan en la costa catalana (Ampurias, Badalona), pero también aparecen en Portla-Nautique (el puerto de Narbona) y en yacimientos del sur de Francia (Vieille-Toulouse y Agen).

La marca Q·MEVI se documenta en Badalona, Castell de la Fosca (Palamós) y Ampurias, y ya en la Galia en los yacimientos de Ruscino, Grand Bassin, Vieille Toulouse y Vesubium (Miró 1988a : 218; Comas 1997: 17). El sello P·MEVI aparece en el pecio de Cap Béar, en Francia. L·VENVLEI se documenta en Ampurias (en cuya zona pudo producirse), el cabo de Creus y, ya en Francia, en Vieille-Toulouse y Agen. L·VOLTEIL, producida al parecer en el taller del Sot del Camp (Sant Andreu de Llavaneres), cerca de Mataró (Barcelona), o en las proximidades de Badalona, se documenta en Cataluña también en las islas Formigues, y en Francia en Narbona, el eje del Garona y los Pirineos atlánticos. M·LOREI aparece en Port-la-Nautique, que era el puerto de Narbona (Pena y Barreda 1997: 55 y 66; Pena 1998: 308 y 317). Sin embargo, la mayoría tienen una difusión mucho más restringida: C·MVCI aparece en Badalona y Vinyoles d'Orís (comarca de Osona, provincia de Barcelona); SEX·STA... se documenta en Ampurias y Badalona (Almagro 1952; Comas 1997: 18-19; Pena 1998: 309 y 312); L·FVL $\cdot$ LIC aparece en el pecio de Cala Bona (Cadaqués), donde se documenta también la marca Q·MEVI (López y Martín 2008: 53-54).

\section{DISCUSIÓN DE LA EVIDENCIA}

Poco o nada podemos decir por ahora sobre quién estaba detrás de la elaboración de las primeras imitaciones de ánforas greco-itálicas y Dressel 1, que evidentemente comportaron una implicación dentro del sistema organizativo y del circuito comercial de la producción y exportación de vino, que hasta entonces (siglo I a.C.) estaba monopolizado por Italia. Las marcas con textos ibéricos nada nos dicen sobre la propiedad de la tierra ni sobre los responsables del proceso productivo, únicamente que los trabajadores de la misma son todavía netamente ibéricos, usando su escritura antes de la extensión de la latina. Por otro lado, los nombres latinos (de los que sólo se ha documentado con seguridad un Quintus Fabius) por sí solos no permiten grandes precisiones ni identificación alguna de personajes.

La situación cambia radicalmente con la aparición del ánfora Tarraconense 1, pues por primera vez se documenta una distribución importante a lo largo de la costa catalana y una difusión apreciable en el sur de las Galias, siguiendo quizás el curso del Ródano pero especialmente del Garona hacia el Atlántico. Ello prefigura la ruta inmediatamente posterior seguida por los vinos envasados en las ánforas de la forma Pascual 1, que sigue la anterior distribución de vinos itálicos; recordemos que la zona de Toulouse es el área francesa donde se documenta una mayor cantidad de ánforas Dressel 1 itálicas (Tchernia 1986: 80). Ello implica un inicio de la sustitución en el sur de la Galia de las importaciones itálicas por las hispánicas, que se consumó con la aparición y distribución de las ánforas de la forma Pascual 1. La por entonces reciente conquista de la Galia Transalpina por parte de César posibilitó sin duda la apertura a gran escala de estos mercados a las producciones vinarias layetanas y tarraconenses. Se perfila también, a partir de los hallazgos, el importante papel de Narbona como gran puerto redistribuidor de estos vinos.

Aunque la datación se discute, los hallazgos de los pecios (cuyo valor como conjuntos cerrados no podemos desestimar) permiten suponer que las ánforas de la forma Tarraconense 1 se estaban exportando hacia los años 40-30 a.C. No es posible plantear cuantificaciones, pero parece ser que la presencia de sellos es bastante abundante en estas ánforas, comparativamente más que en las producciones posteriores (salvo en las Oberaden 74). Los textos casi siempre corresponden a la inicial del praenomen y el nomen más o menos completo. Son bastante aparentes y legibles, lo que puede llevar a entrar en discusiones sobre su utilidad; sin embargo, difícilmente pueden ser otra cosa que indicaciones internas del proceso productivo de las figlinae (Revilla 2004; Berni y Revilla 2008).

Un elemento importante que debemos tener en cuenta es la total ausencia de la forma Tarraconense 1 en los talleres del área de Barcino (Berni y Carreras 2001), tanto en su área suburbial como en la importante zona fabril del Llobregat, que al parecer son coetáneos de la fundación de la ciudad (entre los años 12 y 8 a.C.), lo que es otro indicio de que la cronología de las ánforas de la forma Tarraconense 1 tiene que ser anterior. Tampoco podemos descartar que en otros centros siguiese produciéndose durante algunos años, aunque parece poco probable, teniendo en cuenta los datos cronológicos proporcionados por los pecios.

Como ya ha estudiado Pena (1998) y se abunda con los casos más recientes (la documentación de los sellos de Marcus Antonius y de Publius Heidius) los personajes mencionados en los sellos son, con toda probabilidad, itálicos que no residían en Hispania. La presencia 
o ausencia de determinados nomina en las inscripciones imperiales parece un buen sistema para comprobar si corresponden o no a personajes que se hubiesen establecido en la zona que estudiamos. Los resultados son concluyentes: nomina como Heidius, Loreius, Mevius o Venuleius corresponden a personas que no dejaron descendientes conocidos (o apenas) en la costa este de Hispania, por lo que habrá que concluir que se trata de personajes foráneos. Salvo quizás el caso de Marcus Antonius (y posiblemente éste también como veremos), todos los demás son ingenui, como mucho pertenecientes a la élite municipal.

Una vez llegados a este punto, se hace necesario plantearse cuál era el papel de estos personajes en el proceso de producción. Una posibilidad sería que se tratase de negotiatiores, como sugieren Christol y Plana (1997) para el Usulenus Veiento cuyo nombre aparece en las ánforas de la forma Pascual 1 del taller de Llafranc. Existen noticias históricas y evidencias epigráficas, recogidas por Pena y Barreda (Pena y Barreda 1997; Pena 1998) referentes a algunos personajes con los mismos nomina que aquí nos ocupan, y que con mucha probabilidad habían sido negotiatores. En Delos se hallaron dos inscripciones de finales del siglo II o inicios del I aC en dos catálogos de suscriptores hallados en el Serapeion, que mencionan sendos Mevii: C. Caios Mevios Publi (filius o libertus) i Lucios Mevios (Pena 1998: 307). En época republicana se ha constatado un $C$. Venoleius en una inscripción de la isla de Delos (CIL I, 2, 2238), datada hacia 142 -139 aC. Por otro lado, Cicerón (Ad. Att., VI,1.6) menciona cierto Sex. Statius, un protegido de Pompeyo que probablemente era un negotiator con intereses en la provincia de Cilicia (Pena 1998: 310).

Sin embargo, los nombres mencionados en los sellos de las ánforas de la forma Tarraconense 1 creemos que difícilmente pueden corresponder a negotiatores. El caso de P. Usulenus Veiento, que aparece mencionado tanto en ánforas de la forma Pascual 1 como en las tégulas producidas en el taller de Llafranc, creemos que no responde a este perfil, pese a que así lo han supuesto Christol y Plana (1997 y 1998) pues no resulta demasiado creíble que un negotiator hiciera marcar, no solamente las ánforas, sino también las tégulas. En cambio, Gianfrotta (1982) considera que las marcas en ánforas Pascual 1 con el sello Lentulus Augur indican que éste personaje tenía alguna propiedad rural en la costa de la Hispania Citerior. Por lo tanto, hemos de pensar que los personajes mencionados en los sellos son los responsables del proceso productivo de la figlina (lo que incluye, como se ha visto, otros materiales, como las tégulas), con lo cual lo más razonable creemos que es plantearse que son los propietarios de las tierras en las que ésta se enclavaba.

En el mismo sentido podemos interpretar la mención de personajes de la aristocracia romana en la producción anfórica adriática (Zaccaria 1989), así como el hecho de que en algunas ánforas tardo republicanas aparezca un nombre en la marca de las ánforas y otro en los tapones de puzolana que las sellaban, siendo interpretados estos últimos como los auténticos negotiatores (Tchernia 1986: 118-119). No podemos aducir paralelos tan claros para el caso de la forma Tarraconense 1, pero podemos plantear la posibilidad de un proceso similar.

Llama la atención el probable origen geográfico de estos personajes, atendiendo a la origo del nomen. Mientras algunos (M. Antonius, L. Fulvius, C. Mucius, posiblemente $M$. Cornelius) podrían ser de origen romano o latino, la mayoría proceden del sur y el sudeste de Italia, es decir, que son itálicos strictu sensu. Así, $M$. Loreius parece proceder de Campania (posiblemente de Pompeya), así como quizás L. Venuleius. P. y Q. Mevius (tal vez hermanos, o padre e hijo) probablemente fuesen originarios del sur del Lacio o Campania. En cuanto al resto, todos parecen proceder de la Italia centro-meridional, lo que es un dato a retener; éste podría ser el caso de Sex. Statius, mientras que L. Volteilius / Voltilius es posible que procediese del Lacio meridional o del área samnita, y P. Heidius casi con seguridad procedía de la Umbria oriental, dada la concentración de este nomen en las ciudades de Forum Sempronii, Pitinum Mergens y Sentinum.

Como hemos visto, los hallazgos en los pecios nos indican que las marcas $\mathrm{L} \cdot \mathrm{FVL} \cdot \mathrm{LIC}$ o $\mathrm{L} \cdot \mathrm{FV} \cdot \mathrm{LIC}$, Q.MEVI (o MEVI) y L.VOLTEIL se documentan todas ellas hacia los años 40-30 a.C. Sin embargo, podemos plantear también una posible prolongación de la actividad de estos personajes en la producción de ánforas vinarias o tal vez una continuidad familiar, como podría suceder en el caso de los Mevii y de L. Volteilius, cuyas marcas (especialmente la segunda) se documentan también en ánforas de la forma Pascual 1 (Pascual 1991: 81-84 y 89; Comas 1997: 16 y 28). En el caso de los Mevii podemos hipotéticamente establecer una relación, si bien las marcas Q·MEVI y P·MEVI en Tarraconense 1 parecen tener una datación bastante antigua, mientas que MEVI se documenta en Pascual 1 en Badalona en época de Tiberio (Comas 1997: 28) aunque no podemos descartar que se trate de un elemento residual. La marca MEVI aparece en Pascual 1, posiblemente en Oberaden 74 y también al parecer en Dressel 2-4, en 
l'Aumedina (Tivissa, Ribera d'Ebre), en la provincia de Tarragona (Revilla 1993).

Cabe plantearse quiénes eran estos personajes y cuáles eran las razones que les llevaron a implicarse en la producción de ánforas (y por lógica, en la producción vinaria) en la zona costera oriental de la Hispania Citerior. Pena y Barreda (Pena y Barreda 1997; Pena 1998) han llamado la atención sobre la presencia de los nomina Loreius, Mevius, Statius y, especialmente, Voltilius en la epigrafía lapidaria de Narbona, lo que les hace suponer una relación de la colonia de Narbo con los personajes mencionados en las marcas anfóricas, como quedaría claro en el caso de $P$. Usulenus Veiento (Christol y Plana 1997 y 1998) en la fase inmediatamente posterior. Dada la cronología de las mismas, Pena (1998: 325) los relaciona con la instalación de veteranos de Julio César tanto en Narbo como en Emporiae, que parece remontar al año 45 a.C., todavía en vida del dictador.

Pena cree que los personajes citados en las marcas anfóricas no son colonos; aunque no indica las razones, es de suponer que ello lo deduce de la ausencia de sus nomina en la epigrafía lapidaria de la zona. Por ello, plantea la interesantísima hipótesis de que se trate de personajes que hubiesen acaparado tierras en las provincias aprovechando la coyuntura de las guerras civiles, lo cual resulta probable teniendo en cuenta la escasez de tierras ocupables en Italia, lo que provocó la política colonial de César. Es posible que estuviesen ya de algún modo vinculados a la producción vinaria en Italia, como podría indicarlo la presencia de homónimos (pero claramente distintos, pues los praenomina no son los mismos) mencionados en los sellos de ánforas itálicas, probablemente de la forma Dressel 1. Así, Pena (1998: 309) recuerda que aparecen diversos sellos (STATIVS, M·STATIVS, C·STATIVS) en marcas de ánforas cuya procedencia no se detalla en las publicaciones pertinentes, pero como algunas de ellas son de la forma Dressel $1 \mathrm{~B}$ y se han documentado en lugares como Delos o Cartago, creemos que pueden ser de origen itálico. Por ello, sin poder precisar más, es posible que hubiese una o varias familias de la gens Statia (no necesariamente la senatorial) que se dedicaron a la producción vinaria por lo que sus nombres aparecen en los sellos de las ánforas, y uno de ellos podría haber ampliado sus intereses a Hispania en la segunda mitad del siglo I aC.

Aunque no tengamos datos que nos permitan abundar en ello, cabe plantearse si estos personajes (que hoy denominaríamos "inversores"), en el caso probable de que hubiesen adquirido (es posible que a bajo precio, dada la coyuntura bélica y post-bélica) tierras en la zona costera del nordeste de la Hispania Citerior, lo hicieron a partir y a causa de la política colonial de César, o bien si este fenómeno tiene un origen inmediatamente posterior. Nos estamos refiriendo a la situación creada por el Segundo Triunvirato, cuando la política de proscripciones puesta en marcha por los triunviros, así como la posterior situación bélica entre Octavio y Marco Antonio, pudo dar lugar a una situación que pudiese haber sido aprovechada por personajes sin escrúpulos para hacerse con tierras fuera de Italia por medios quizá poco ortodoxos. Se trata por ahora de una hipótesis indemostrable, pero que de algún modo creemos que debería ser explorada. Y en este posible contexto, no hemos de olvidar que uno de los nombres mencionados en las marcas de las ánforas Tarraconense 1 es nada más y nada menos que Marcus Antonius.

A partir de lo que acabamos de comentar, es evidente que el Marcus Antonius mencionado en el sello de las ánforas tarraconenses no tiene por qué ser el famoso triunviro, sobre todo cuando aparece en ánforas de la forma Pascual 1, claramente posteriores al mismo. Sin embargo, ¿es totalmente descartable tal identificación? Podemos traer a colación el caso de algunas ánforas de procedencia adriática, de la forma Lamboglia 2, que presentan en el borde la marca CNP MAG, que se ha sugerido desarrollar como $C$ (naeus) $P$ (ompeius) $M$ (agnus), suponiendo que podrían corresponder a propiedades de Pompeyo Magno (Amela 2011). Amela cita otros casos, como los de Publio Cornelio Sila (consul designatus en $65 \mathrm{aC}$ ), Lucio Cornelio Léntulo (cónsul en 49 a.C.) y quizás el mismo triunviro Marco Licinio Craso como ejemplo de personajes de la alta nobleza que aparecen mencionados en sellos de ánforas itálicas del siglo I a.C., por no citar los casos más conocidos de personajes de la nobleza senatorial cuyos nombres se encuentran en las ánforas adriáticas del siglo I d.C. (Zaccaria 1989). Ello sirve de paso para demostrar que en estos casos sin duda las marcas no aluden para nada a negotiatores. En este sentido, podríamos teorizar que Marco Antonio tenía alguna propiedad en la costa catalana, que quizás anteriormente hubiese pertenecido a Pompeyo, quien probablemente tenía intereses en la zona (Olesti 1993) y cuyas propiedades pasaron en gran parte a manos de Antonio, comenzando por la propia casa de Pompeyo en Roma, situado en el barrio de las Carinae (Cass. Dio 48.38; Flor. 2.18.4-5).

De todos modos, existe un indicio que nos permite cuestionar la identificación con el Marcus Antonius de nuestros sellos con el triunviro. El ejemplar de Blanes, a partir del dibujo publicado y la descripción de la pasta 
("anaranjada con desgrasante a base de mica y cuarzo"; Vilà et al. 1978: 231) no ofrece ninguna duda sobre su identificación con un ánfora Tarraconense 1; sin embargo, se han documentado tres ejemplares de la forma Pascual 1 con la marca M·ANTO (con el mismo texto, pero formalmente distintas), hallados uno en el pecio de Berà (Tarragona) (Pascual 1991: 87) y los otros dos en Port-la-Nautique, el antiguo puerto de Narbona (Bergé 1990: 161, núm. 48; ANTEAS 1993: 38, núm. 154 y Blanch et al. 1998: núm. 48). La forma Pascual 1 difícilmente se puede datar con anterioridad al año 30 a.C., con lo que habría que descartar la identificación del Marcus Antonius mencionado en estos sellos con el triunviro homónimo. En todo caso, lo más probable es que el Marcus Antonius que aquí nos ocupa sea otro miembro de esta familia, quizás de una rama que no fuese de rango senatorial; este sería el caso, por ejemplo, de cierto Marcus Antonius Rufus mencionado en una inscripción de Brindisi, de época de Augusto (Eagle, EDR017350). Tampoco puede descartarse que la marca M-ANTO hiciese referencia a un liberto, si bien el resto de marcas en ánforas Tarraconense 1 apuntan más bien a ingenui, siendo la mención de libertos en las marcas propia de formas anfóricas (Pascual 1, Dressel 2-4) y cronologías algo más recientes.

Como sucedía en la producción de Dressel 1 hispánica, también el ánfora Tarraconense 1 en al menos un caso tuvo un sello con un texto escrito en alfabeto ibérico. Así lo demuestra el hallazgo en Zaragoza de un fragmento de borde donde se lee Eikebi (Aguarod 1992: 109-116). Ello nos está indicando, como ocurría con las Dressel 1, la implicación del elemento indígena en el proceso de producción de la figlina, pero en absoluto la titularidad de la misma, que tiende a poderse desestimar ante el resto de la evidencia epigráfica de las marcas de estas ánforas.

A pesar de la hipótesis de Pena según la cual los personajes mencionados en los sellos de las ánforas de la forma Tarraconense 1 son foráneos y "no se mueren aquí", hemos de tener en cuenta que en Ampurias, Valencia y Cartagena (Pena y Barreda 1997: 56) tenemos documentada la presencia, minoritaria, de los nomina Venuleius/Vinuleius y Voltilius en la epigrafía lapidaria, lo que creemos que no nos permite descartar completamente que los personajes de las marcas anfóricas fuesen colonos cesarianos. Concretamente en la epigrafía de Ampurias (Almagro 1952; Pena 1982; Fabre, Mayer y Rodà 1991) se documentan diversos nomina itálicos que no tienen apenas confronto en el resto de Hispania: Appuleii, Cartilii, Fulvii, Lorei, Minicii, Ovinii, Papirii, Perpernae, Pontienii, Rosii, Sentii, Visuleii y quizás
Ceasonii, Nunidii, Rullii, Voltei y Voltinii, así como dos nomina, Audienii y Fabrinii, absolutamente desconocidos en el resto de la Península. Por ello, Fabre, Mayer y Rodà (1991: 17) consideran que se trata de familias inmigradas de Italia; estos autores llaman la atención sobre la presencia de las tribus Lemonia y Sergia (que sugieren que pudo haber sido la primera tribu de Emporiae, antes de la implantación de la Galeria en tiempos de Augusto). Algunas de estas inscripciones son bastante antiguas, como la que menciona a $C$. Visuleius, que debe ser de época triunviral o augustea (Fabre, Mayer y Rodà 1991: 114-115, núm. 90), o la de L. Papirius Carbo, datada a finales de época republicana (Fabre, Mayer y Rodà 1991: 104-105, núm. 77); la mayoría se fechan hacia la época de Augusto.

Por lo tanto, esta presencia de elementos itálicos permite pensar en una inmigración importante, que podemos poner en relación con la deductio de Julio César en Emporiae. El caso mencionado de L. Papirius Carbo recuerda la onomástica de la notable familia itálica de los Papirii Carbones, pudiendo tratarse de un indígena romanizado o bien un miembro secundario de esta familia; recordemos que un Q. Papirius Carbo está documentado como magistrado monetal en Carthago Nova en época de Augusto (Villaronga 1979: 265). Nos interesa traer a colación también aquí una inscripción ampuritana del siglo I d.C. que menciona a M. Loreius Celer (Fabre, Mayer y Rodà 1991: 100-101, núm. 100101). La misma inscripción menciona una Fulvia y un Fulvius Faustus. No es imposible que este Loreius Celer estuviese emparentado con el que aparece mencionado en el sello del ánfora Tarraconense 1, y quién sabe si también con el L. Fulvius documentado también por un sello anfórico.

No hemos de extendernos aquí en el caso de la colonia Narbo, fundación cesariana en el mismo emplazamiento de la vieja colonia del año 118 a.C., que a partir de entonces tuvo uno de los puertos más pujantes del Mediterráneo occidental y al cual afluyeron las ánforas de la forma Tarraconense $1 \mathrm{y}$, sobre todo, las posteriores Pascual 1 (Bergé 1990). Por otro lado, no hemos de olvidar que en Baeterrae (Béziers) y Ruscino (Castell Rosselló) se produjeron también sendas deductiones cesarianas. Aunque la cronología de todo ello se discute, es muy probable que el desarrollo de esta política colonial se llevase a cabo después de la muerte de César, en época del Segundo Triunvirato. De hecho, el patronus más antiguo conocido en Emporiae es $C n$. Domitius Calvinus, según unas inscripciones (Alföldy 1977-78; Fabre, Mayer y Rodà 1991: 60-63, núms. 26.28) que se pueden fechar a partir del año 36 a.C. 
Llama la atención la relativa proximidad entre sí de las ciudades mencionadas más arriba (a las que habría que añadir la más lejana Arelate, actual Arles). Todas ellas fueron deductiones de origen militar. Así, en Narbo se establecieron veteranos de la décima legión (decumani), en Baeterrae los de la VII legión (septimani), mientras que en Arelate y Ruscino se instalaron los veteranos de la VI (sextani). No sabemos a qué legión correspondían los veteranos que se asentaron en Ampurias, según el testimonio de Tito Livio (Ab urbe condita, XXXIX, 9), ni tampoco el status de la ciudad, que en todo caso era un municipium en época de Augusto, no una colonia como las otras mencionadas. Ello formaba parte de un proyecto más vasto, ya que, según Suetonio, César concedió tierras a 80.000 plebeyos de la ciudad de Roma (Suetonio, Iul, 42, 1) y a 20.000 veteranos, según Plutarco (César, 57), quien hace mención explícita a la refundación de Corinto y Cartago. Aunque es dudoso, parece ser que la deductio colonial de Tarraco habría sido también ideada para establecer a soldados veteranos (Hoyos 1975; Ruíz de Arbulo 2002).

No está clara la cronología de estas fundaciones, que muy posiblemente son posteriores al asesinato de César, desarrollándose probablemente en época del Segundo Triunvirato, como en el caso de la Colonia Victrix Iulia Lepida en el solar de la antigua Celsa, nombre que no deja dudas sobre su fundación por Lépido, sin duda después de la muerte de César, coincidiendo con la presencia de este personaje en Hispania en los años 42-43 a.C. (Roddaz 1988: 328-329). También la colonia Urbs Iulia Nova Karthago parece haber sido fundada por Lëpido en las mismas fechas, según se deduce de la numismática (García y Bellido 1961-62: 369370). Por la identidad de la titulación de Carthago Nova, podríamos suponer que la colonia de Tarraco se fundó también en estos años, en contra de la cronología más alta (Ruíz de Arbulo 2002) que se ha sugerido recientemente.

En cualquier caso, está clara la importancia del elemento militar en la fundación de los establecimientos coloniales (fuese cual fuese su status) de Narbo, Baeterrae, Ruscino y Emporiae. Por lo tanto, creemos que no debe descartarse que algunos de los veteranos asentados en el territorio se dedicasen a la explotación vitivinícola, siendo al menos en parte los que aparecen mencionados en los sellos de las ánforas de la forma Tarraconense 1. Tampoco podemos descartar la llegada de especuladores foráneos, atraídos por la fundación de estas colonias. El papel preponderante que tuvo Narbo como centro distribuidor de los vinos layetanos y tarraconenses en época de Augusto, así como la presencia de notables narbonenses implicados en esta distribución, como se demuestra en el caso del Usulenus Veiento que selló ánforas de la forma Pascual 1 (Christol y Plana 1997 y 1998), hacen pensar que ya desde la deductio de la colonia fue éste un centro importante, donde pudieron radicarse los comerciantes implicados en la distribución de estos productos. No podemos descartar, de forma quizá subsidiaria, el papel de la ciudad de Emporiae, donde encontramos algunos cognomina que aparecen también en los sellos de las ánforas de la forma Tarraconense 1, y en cuyas cercanías parecen haberse producido las que llevan el sello L.VENVLEI.

Por lo tanto, parece evidente que la colonización cesariana o triunviral resultó el detonante que provocó un salto cualitativo en la producción y comercialización vinaria, reflejada en la elaboración de las ánforas de la forma Tarraconense 1. Pese a lo que se ha dicho no es descartable que los mismos colonos, al menos en parte, tuviesen una implicación directa en este proceso de producción, sin descartar la presencia de elementos foráneos, o bien de una situación mixta, promovida por el nuevo proceso de urbanización y romanización.

La presencia en los pecios de las marcas L · VOLTEIL, $\mathrm{L} \cdot \mathrm{FVL} \cdot \mathrm{LIC}$ y Q $\cdot \mathrm{MEVI}$ en contextos de los años 50-30 a.C. respaldan una datación antigua, y la mayoría de los nombres mencionados en los sellos de las ánforas Tarraconense 1 no aparecen después en Pascual 1, lo que debe reflejar algunos cambios en el proceso productor y comercializador de los vinos de la zona estudiada. Por otro lado, con la aparición de las ánforas Pascual 1 entran en escena nuevos nombres de personajes foráneos, como Publius Usulenus Veiento de Narbo (Christol y Plana 1997 y 1998), Publius Baebius Tuticanus, de Verona (Tremoleda 1998), Caius Mussidius Nepos, de Sulmona (Barreda 1998), en Italia, así como probablemente Caius Antestius o Antistius (Miró 1988a: 222; Comas 1997: 22-23; Pena 1998: 311) que no aparecen mencionados en las ánforas de la forma Tarraconense 1. Por ello, podemos suponer que al menos durante la primera mitad del imperio de Augusto debieron seguir produciéndose las condiciones que habían llevado a personajes foráneos como los que hemos estudiado a involucrarse en la producción de vino en el nordeste de la Hispania Citerior.

Tan sólo las marcas de L·VOLTEIL y MEVI parecen tener una continuidad en períodos posteriores, pues L·VOLTEIL se documenta abundantemente en ánforas Pascual 1 (Miró 1988a: 221; Comas 1997: 16). Además de las marcas Q·MEVI y P·MEVI en la forma Tarraconense 1, se documenta la forma MEVI en Pascual 1, 
posiblemente en Oberaden 74 y también al parecer en Dressel 2-4 (Comas 1997: 28; Revilla 1993; González y Járrega 2011); No solamente tenemos aquí una aparente continuidad, sino además un desplazamiento geográfico, ya que la marca Q·MEVI en Tarraconense 1 parece poder relacionarse con el área ampuritana o badalonesa, mientras que la marca MEVI aparece en una posible Oberaden 74 al parecer producida en la costa meridional catalana (González y Járrega 2011). Es un fenómeno parecido al de la marca SEX·DOMITI en la forma Oberaden 74, que se documenta tanto en el mencionado taller de l'Aumedina (Tivissa) como en el de La Canaleta (Vila-seca), cerca de Tarragona (Revilla 1993; Gebellí y Járrega 2011). Por cierto, que este Sextus Domitius, personaje de época de Augusto imposible de identificar desde el punto de vista prosopográfico, podría haber sido también de origen foráneo y responder a la misma dinámica económica que hemos estudiado más arriba.

\section{CONCLUSIONES}

- Las primeras ánforas vinarias elaboradas a partir de modelos romanos en lo que hoy es Cataluña aparecieron en el siglo II a.C., si bien las cronologías no son muy claras. Se produjeron imitaciones de ánforas greco-itálicas y de la forma Dressel 1 A y, especialmente, B, incluso en algunos casos de tamaño muy pequeño, como en el taller de El Vilar (Valls).

- La geografía de estas producciones se circunscribe hasta ahora a la costa central layetana (en el área del poblado ibérico de Burriac y sus alrededores), así como en su inmediato hinterland (comarca del Vallès Occidental). Se documenta también en el interior del ager Tarraconensis (taller de El Vilar de Valls).

- La epigrafía presente en estas ánforas es muy escasa; en la comarca tarraconense del Alt Camp se han documentado sellos con texto ibérico, que prueban el papel de los indígenas en el proceso de elaboración de las ánforas. También contamos con epigrafía latina, con nomina latinos (Q·FABI). No sabemos si la iniciativa de la producción estaba en manos de personajes indígenas romanizados o foráneos; se ha discutido sobre el tema sin poder llegar a ninguna conclusión cierta.

- Podemos suponer que los nomina latinos que aparecen en las ánforas Dressel 1 corresponden a elementos itálicos mejor que indígenas romanizados, teniendo en cuenta que la organización de la producción vinaria exigía tener cierto capital y alguna introducción en el mercado. Es posible que, más que de negotiatores, se tratase de possesores instalados en las primeras (y escasas) villae republicanas.

- La difusión exterior de estas ánforas no parece haber sido muy importante; en todo caso, no tiene parangón con las masivas importaciones de los vinos itálicos, envasados también en ánforas de la forma Dressel 1. Su presencia es segura en Mallorca y Menorca, así como al parecer también en el sur de Francia (Burdeos y el pecio de Cap-Béar 3), aunque no es seguro que se trate de producciones de la Hispania Citerior o que sean itálicas.

- La producción de ánforas de la forma Tarraconense 1 representa un cambio cuantitativo y cualitativo importante, después de la esporádica producción de ánforas de la forma Dressel 1. Aumentan considerablemente tanto el número de centros productivos como la epigrafía anfórica, muy presente en este tipo de ánforas y, por lo tanto, en esta fase productiva.

- El área de producción de las ánforas de la forma Tarraconense 1 es, a diferencia de las anteriores Dressel 1, bastante variada. Puede suponerse con bastante seguridad que se producían en la zona de Ampurias, a juzgar por la concentración de la marca L.VENVLEI; en relación con esta ciudad habría que poner los centros de producción de Fenals, el Collet de Sant Antoni y Llafranc. La zona principal se sitúa en la costa central catalana, en la comarca del Maresme, en relación con las ciudades de Iluro y Baetulo. Se documenta también en el "hinterland" interior, es decir, en la comarca del Vallès Occidental (figlina de La Salut). En la costa meridional, tenemos documentada su posible producción en los talleres de El Vilarenc y Tomoví, que hemos de poner en relación con la ciudad de Tarraco. En todo caso, se trata de una producción focalizada en la zona septentrional y central de la costa catalana (Costa Brava, el Vallès y el Maresme), con una posible extensión hacia el área oriental del ager Tarraconensis.

- La cronología de estas ánforas se ha situado grosso modo entre los años 40 y 30 a.C. Si bien se ha supuesto su producción hasta el cambio de Era, basándose en los datos estratigráficos de yacimientos terrestres en Cataluña y el sur de Francia, lo cierto es que las fechas proporcionadas por los pecios, con su valor como conjuntos cerrados, no permiten por ahora superar la cronología del 30 a.C. 
aproximadamente. Por ello, las dataciones de los ejemplares de yacimientos de tierra firme pueden ser equivocadas, y los ejemplares documentados aparecer en estado residual. La ausencia de esta forma en los talleres del área de Barcino, que al parecer son coetáneos de la fundación de la ciudad (entre los años 12 y 8 a.C.), es otro indicio de que la cronología de las ánforas de la forma Tarraconense 1 tiene que ser anterior.

- Esta datación tan limitada en el tiempo tiene que responder históricamente a unas circunstancias muy determinadas. Corresponde por lo tanto a época cesariana y, con mayor seguridad, del Segundo Triunvirato, cuando se llevaron adelante los planes coloniales ideados por Julio César. Es por lo tanto a la luz de este contexto histórico que tenemos que interpretar la producción de estas ánforas.

- La difusión de las ánforas de la forma Tarraconense 1 está mucho más extendida que la de las Dressel 1 de la Hispania Citerior, penetrando hacia el interior hasta Zaragoza remontando el Ebro, y apareciendo también en el norte de la Comunidad Valenciana y en diversos yacimientos de las Baleares. Se distribuye también en la Galia a lo largo de las rutas del Ródano y del Garona hasta Bretaña.

- Los sellos de las ánforas Tarraconense 1 hacen siempre referencia a nomina latinos. Solamente en un caso documentado en Zaragoza aparece una marca con un texto ibérico, que no ha sido posible interpretar. Se trata de una decena escasa de nombres (Marcus Antonius, Publius Heidius, Caius Iunius, Marcus Loreius, Quintus Mevius, Caius Mucius, Caius Servilius, Sextus Statius, Lucius Venuleius y Lucius Volteilius -o Voltilius-, y posiblemente Marcus Cornelius) cuya escasa o nula relación con la epigrafía lapidaria de la zona ha hecho suponer, como sugería M.J. Pena, que hacen referencia a personajes foráneos.

- Los paralelos epigráficos conocidos permiten plantear el posible origen de estos personajes. Algunos (M. Antonius, L. Fulvius, C. Mucius, posiblemente $M$. Cornelius) podrían ser de origen romano o latino, pero la mayoría proceden del sur y el sudeste de Italia.

- Aunque resulta muy probable la hipótesis de Pena según la cual los personajes mencionados en los sellos hubiesen acaparado tierras en las provincias aprovechando la coyuntura de las guerras civiles, la presencia en la epigrafía lapidaria de época imperial en Ampurias, Valencia y Cartagena de los nomina Fulvius, Loreius, Venuleius y Voltilius creemos que no permite descartar completamente que los personajes de las marcas anfóricas fuesen colonos cesarianos. Por ello, no es imposible que los mismos colonos hubieran tenido un papel directo en el proceso de producción, sin descartar la presencia de otros elementos foráneos.

- La presencia de nombres de personajes homónimos aunque distintos (los praenomina son diferentes) en los sellos de las ánforas itálicas contemporáneas hace posible que los personajes citados en las marcas estuviesen ya de algún modo vinculados a la producción vinaria en Italia.

- En todo caso, y después de las primeras y vacilantes producciones de ánforas vinarias de la forma Dressel 1, podemos concluir que la con la forma Tarraconense 1 se produjo un rápido salto cualitativo en la producción vinícola de la costa catalana, que corresponde probablemente a cambios en la gestión y que prefigura la generalización de la producción que se produjo en época de Augusto con las ánforas de la forma Pascual 1.

\section{Agradecimientos}

Este trabajo ha sido llevado a cabo con en el marco del proyecto de I+D "Amphorae ex Hispania. Paisajes de producción y consumo", financiado por el Ministerio de Ciencia e Innovación (código: HAR2011-28244).

Agradecemos a Albert Martín, director de la excavación El Roser o El Mujal (Calella, Barcelona), la información sobre este yacimiento y la autorización para usar estas noticias, así como habernos permitido publicar un ejemplar inédito.

\section{BIBLIOGRAFÍA}

Aguarod, C. (1992): “Un ánfora Tarraconense 1 / Layetana 1 con sello ibérico procedente de Salduie". Boletín del Museo de Zaragoza 11: 109-116.

Alföldy, G. (1977-78): “Cnaeus Domitius Calvinus, patronus von Emporiae". Archivo Español de Arqueología 50-51: 47-56.

Almagro, M. (1952): Las inscripciones ampuritanas griegas, ibéricas y latinas. Barcelona, Instituto Español de Prehistoria del CSIC y Servicio de Investigaciones Arqueológicas de la Diputación Provincial.

Amela, L. (2011): "Las ánforas de Pompeyo Magno". Sylloge Epigraphica Barcinonensis IX: 193-205. 
ANTEAS (1993): Rapport Fouille de Sauvetage $n^{\circ}$ 001714 Realisé du 18.12 au 25.04.1993 Site: Port La Nautique Narbonne (Aude). Narbona, ANTEAS, Association Narbonnaise de Travaux et d'Études Archéologiques Subaquatiques.

Aquilué, X.; Mar, R.; Nolla, J.M.; Ruiz de Arbulo, J. y Sanmartí, E. (1984): El fòrum romà d'Empúries (excavacions de l'any 1982). Una aproximació arqueològica al procès històric de la romanització al nord-est de la península ibèrica, Monografies emporitanes 6. Barcelona, Diputación de Barcelona.

Barreda, A. (1998): "La gens Mussidia en las ánforas Pascual 1", en $2 n$ Col-loqui Internacional d'Arqueologia Romana. El vi a l'Antiguitat, economia, producció $i$ comerç al Mediterrani Occidental. Monografies Badalonines 14: 332-340. Badalona, Museu de Badalona.

Beltrán Lloris, M. (2008): "Las ánforas tarraconenses en el valle del Ebro y la parte occidental de la provincia tarraconense", La producción i el comerç de les àmfores de la Provincia Hispania Tarraconensis. Homenatge a Ricard Pascual i Guasch: 271-317. Barcelona, Museu d'Arqueologia de Catalunya.

Bergé, A. (1990): "Les marques sur amphores Pascual 1 de Port-la-Nautique". Cahiers d'Archeologie Subaquatique 9: 131-201.

Berni, P. y Carreras, C. (2001): "El circuit comercial de Barcino: reflexions al voltant de les marques amfòriques". Faventia 23/1: 103-129.

Berni, P.; Carreras, C. y Revilla, V. (1998): "Sobre dos nuevos Cornelii del vino tarraconense". Laietània 11: 109-123.

Berni, P.; Clariana, J.-F. y Járrega, R. (2012): “Una nueva marca de ánfora de la forma Tarraconense 1 procedente de la comarca del Vallès Oriental (Barcelona)". Ex Officina Hispana, Boletín 4: 22-23.

Berni, P. y Járrega, R. (2012): "Epigrafía anfórica romana de época tardorrepublicana en las comarcas del Baix Ebre y el Montsià (Tarragona)". Ex Officina Hispana, Boletín 4: 20-22.

Berni, P. y Miró, J. (2013): “Dinámica socioeconómica en la Tarraconense Oriental a finales de la República y comienzos del Imperio. El comercio del vino a través de la epigrafía anfórica”, en J. López Vilar (ed.), Tarraco Biennal: 1er Congrés Internacional d'Arqueologia i Món Antic. Govern i societat a la Hispània romana. Novetats epigràfiques. Homenatge a Géza Alföldy: 63-83. Tarragona, Fundació Privada Mútua Catalana.

Berni, P. y Revilla, V. (2008): “Los sellos de las ánforas de producción tarraconense: representaciones y significado", en La producción i el comerç de les àmfores de la Provincia Hispania Tarraconensis. Homenatge a Ricard Pascual i Guasch: 95-111. Barcelona, Museu d'Arqueologia de Catalunya.

Berthault, F. (2009): "Les amphores de Bordeaux-Chapeau-Rouge; étude sur les relations commerciales de Burdigala au début de l'Empire'. Aquitania 25: 143-197.

Blanc-Bijon, V.; Carre, M. B.; Hesnard A. y Tchernia, A. (1998): Recueil de timbres sur amphores romaines II (1989-1990 et compléments 1987-1988). Aix en Provence, Publications de l'Université de Provence.

Carre, M. B.; Gaggadis-Robin, V.; Hesnard, A. y Tchernia, A. (1995): Recueil de timbres sur amphores romaines (1987-1988). Aix en Provence, Publications de l'Université de Provence.

Carreté, J.M.; Keay, S. y Millett, M. (1995): A Roman provincial capital and its hinterland. The survey of the territory of Tarragona, Spain, 19851990. Journal of Roman Archaeology, Supplementary series 15. Rhode Island, US, Journal of Roman Archaeo$\log y$

Casas, M.T. (1987): "Estudi preliminar: estudi de les àmfores de la vil·la de la Salut, Sabadell”. Arraona 1: $15-26$

Christol, M. y Plana, R. (1997): "Els negotiatores de Narbona i el vi català". Faventia 19/2: 75-95.

Christol, M. y Plana, R. (1998): "De la Catalogne à Narbonne: épigraphie amphorique et épigraphie lapidaire. Les affaires de Veiento“, en Actes de la $I X^{e}$ Rencontre franco-italienne sur l'épigraphie $d u$ monde romain: 273-302. École Française de Rome / Università di Macerata (1995), Pisa, Istituti editoriali e poligrafici internazionali.

CODEX (1992): "Excavacions a l'autopista A-19, variant de Mataró. Tres exemples de poblament del Maresme: de l'ibèric ple a la romanització". Laietània 7 : 155-189.

CODEX (1995a): "Forns de Can Portell", en Autopistas i Arqueologia: 43-55. Barcelona, Generalitat de Catalunya.

CODEX 1995b: "Can Balençó", en Autopistas i Arqueologia: 57-88. Barcelona, Generalitat de Catalunya.

Colls, D. (1986): "Les amphores léetaniennes de l'épave de Cap Béar III", en Hommage à Robert Etienne. Revue des Études Anciens LXXXVIII, 17: 201-213.

Comas, M. (1985): Baetulo. Les àmfores. Badalona, Museu de Badalona. 
Comas, M. (1997): Baetulo. Les marques d'àmfora. Corpus International des Timbres Amphoriques (fascicule 2). Barcelona, Union Académique Internationale Institut d'estudis Catalans - Museu de Badalona.

Comas, M. (1998): "La producció i el comerç del vi a Baetulo. Estat de la questió", en El vi a l'Antiguitat, economia, producció $i$ comerç al Mediterrani Occidental. Monografies Badalonines 14: 219-232. Badalona, Museu de Badalona.

Comas, M. y Casas, T. (1989): "Nuevas aportaciones para el conocimiento del ánfora Laietana 1: cronología, difusión y producción”, en Amphores romaines et histoire économique: dix ans de recherche (Actes du colloque de Sienne, 22-24 mai 1986), / Anfore romane e storia economica: un decennio di ricerche: 580-585. Siena (1986), Roma, École Française de Rome / Paris, Diffussion De Boccard.

Comas, M.; Martín, A.; Matamoros, R. y Miró, J. (1998): "Un nou tipus d'àmfora Dressel 1 de producción laietana", en De les estructures indígenes a l'organització provincial romana de la Hispània citerior: homenatge a Josep Estrada i Garriga. Ítaca, Quaderns catalans de Cultura Clàssica, any 1998. Annexos 1: 149-161. Barcelona, Institut d'Estudis Catalans / Societat Catalana d'Estudis Clàssics.

Corell, J. y Gómez, X. (2009): Inscripcions romanes del País Valencià V (Valentia i el seu territori). Valencia, Universidad de Valencia.

Corzo, R. (1982): "Un taller de ceramista en la bahía de Cádiz: Gaius Iunius Dracus", en Homenaje a Sáenz de Buruaga: 389-396. Badajoz, Institución Cultural Pedro de Valencia, Diputación de Badajoz.

Desy, P. (1989): Le timbres amphoriques de l'Apulie républicaine: documents pour une histoire économique et sociale. BAR International Series 554. Oxford, British Archaeological Reports.

Díaz Ariño, B. (2008): Epigrafía latina republicana de Hispania. Col. Instrumenta 26, Barcelona, Universitat de Barcelona.

Donne, W.B. (1870): "Mucia gens", en W. Smith (ed.), Dictionary of Greek and Roman Biography and Mythology vol. 2: 1117. Boston, Little, Brown and co.

Dressel, H. (1899): Corpus Inscriptionum Latinarum, XV.2: Inscriptiones Urbis Romae Latinae. Instrumentum domesticum. Partis posterioris fasciculus I. Berlín, ed. G. Reimer.

EAGLE Electronic Archive of Greek and Latin Epigraphy. International federation of Epigraphic Databases. Under the patronage of Association International
d'Epigraphie Grecque et Latine - AIEGL (recurso electrónico; http://www.eagle-eagle.it).

Fabre, G.; Mayer, M. y Rodà, I. (1991): Inscriptions romaines de Catalogne III. Gerone. París, Diffussion De Boccard.

Fernández Izquierdo, A. (2006): “Aproximación a la villa romana de Mas d'Aragó (Cervera del Maestrat, Castellón): producción cerámica del alfar". Quaderns de Prehistòria i Arqueologia de Castelló 25: 271-300.

Foerster, F.; Pascual, R. y Barberà, J. (1987): El pecio romano de Palamós. Excavación arqueológica submarina. Barcelona, Centro de Recuperación e Investigaciones Submarinas (CRIS).

Gabba, E. (1973): Esercito e società nella tarda repubblica romana. Florencia, La Nuova Italia.

García y Bellido, A. (1961-62): "Las colonias romanas de Valentia, Carthago Nova, Libisosa e Ilici. Aportaciones al estudio del proceso de romanización del S.E. de la Península", en Homenaje al Profesor Cayetano de Mergelina: 367-372. Murcia, Universidad de Murcia.

García, J. y Gurri, E. (1996-97): "Les imitacions laietanes d'àmfores itàliques a la zona central de la comarca del Maresme en època tardorepublicana", en Annals de l'Institut d'Estudis Gironins (Hispània i Roma. D'August a Carlemany. Congrès d'homenatge al Dr. Pere de Palol): 397-424. Girona, Institut d'Estudis Gironins.

García Vargas, E.; de Almeida, R. y González Cesteros, H. (2011): "Los tipos anfóricos del Guadalquivir en el marco de los envases hispanos del siglo I a. C. Un universo heterogéneo entre la imitación y la estandarización”. Spal 20: 185-283.

Gebellí, P. y Járrega, R. (2011): “La terrisseria romana de la Canaleta (Vila-seca) “, en M. Prevosti y J. Guitart (eds.), Ager Tarraconensis 2. El poblament. The population. Serie Documenta 16: 547-562. Tarragona, Institut Català d'Arqueologia Clàssica.

Gianfrotta, P. (1982): "Lentulo Augure e le anfore laietane", en Tituli 4, Atti del Colloquio Internazionale AIEGL su Epigrafia e ordine senatorio, I: 475-479. Roma (1981), Roma, Edizioni di storia e letteratura.

González, H. y Járrega, R. (2011): “Un fragmento de ánfora tarraconense de la forma Oberaden 74 con el sello MEVI, hallado en Tarraco (Tarragona)". Ex Officina Hispana, Boletín 3: 19-21.

Hoyos, B.D. (1975): "Civitas and Latium in Provincial Communities: Inclusion and Exclusión". Revue Internationale des Droits de l'Antiquité 22: 274-276. 
Járrega, R. (2000): “El poblament rural i l'origen de les villae al NordEst d'Hispania durant l'època romana republicana (segles III a. de J.C.)". Quaderns de Prehistòria i Arqueologia de Castelló 21: 271-301.

Járrega, R. y Abela, J. (2011): "Producció i importació de ceràmiques a l'ager Tarraconensis. Una aproximació a l'economia del Camp de Tarragona en època romana“, en M. Prevosti y J. Guitart (eds.), Ager Tarraconensis 2. El poblament: 141-207. Tarragona, Institut Català d'Arqueologia Clàssica.

Járrega, R. y Prevosti, M. (2011): "Figlinae tarraconenses. La producció ceràmica a l'ager Tarraconensis“, en M. Prevosti y J. Guitart (eds.), Ager Tarraconensis 2. El poblament: 455-489. Tarragona, Institut Català d'Arqueologia Clàssica.

Lauranceau, N. (1988): "Les amphores des zones 10 et 11", en Les fouilles de "Ma Maison". Etudes sur Saintes antique. Aquitania Suppl. 3: 263-278.

Long, L. (1998): “Lucius Volteilius et l'amphore de 4ème type. Découverte d'une amphore atypique dans une épave en baie de Marseille", en $2 n$ Col-loqui Internacional d'Arqueologia Romana. El vi a l'Antiguitat, economia, producció i comerç al Mediterrani Occidental. Monografies Badalonines 14: 341-349. Badalona, Museu de Badalona.

López, A. y Martín, A. (2008): “Tipologia i datación de les àmfores tarraconenses produïdes a Catalunya", en La producción i el comerç de les àmfores de la Provincia Hispania Tarraconensis. Homenatge a Ricard Pascual i Guasch: 33-94. Barcelona, Museu d'Arqueologia de Catalunya.

Manacorda, D. (1986): "A proposito delle anfore cosiderre "greco-italiche": una breve nota", en J.-Y. Empereur e Y. Garlan (eds.), Recherches sur les amphores grecques. Bulletin de Correspondance Hellénique Supplément X: 581-586. Atenas (1984), París, Ecole Française d'Athènes.

Manacorda, D. (1990): "Le fornaci di Visellio a Brindisi: primi risultati dello scavo". Vetera Christianorum 27: 375-415.

Manacorda y Pallecchi, S. (2012): Le fornaci romane di Giancola (Brindisi). Bibliotheca Archeologica 27. Bari, Edipublia.

Martín, A. y Prevosti, M. (2003): “El taller d'àmfores de Tomoví i la producció amfòrica a la Cossetània oriental“", en J. Guitart, J.M. Palet y M. Prevosti (eds.), Territoris antics a la Mediterrània $i$ a la Cossetània oriental. Simposi Internacional d'Arqueologia del Baix Penedès: 231-237. Barcelona, Generalitat de Catalunya.
Miró, J. (1988a): "Les estampilles sobre àmfores catalanes. Una aportació al coneixement del comerç del vi del Conventus Tarraconensis a finals de la República i principis de l'Imperi“, en M. Mayer e I. Rodà, Epigrafia, Fonaments 7: 243-263.

Miró, J. (1988b): La producción de ánforas romanas en Cataluña. Un estudio sobre el comercio del vino de la Tarraconense (siglos I a.C.-I d.C.). BAR International Series 473. Oxford, British Archaeological Reports.

Nieto, X. y Raurich, X. (1998): "El transport naval de vi de la Tarraconense", en $2 n$ Col-loqui Internacional d'Arqueologia Romana. El vi a l'Antiguitat, economia, producció i comerç al Mediterrani Occidental. Monografies Badalonines 14: 113-137. Badalona, Museu de Badalona.

Nolla, J.M. (1974-75): "Las ánforas romanas de Ampurias". Ampurias 36-37: 147-197.

Nolla, J.M. (1987): "Una nova àmfora catalana: la Tarraconense 1", en El vi a l'Antiguitat. Economia, producció i comerç al Mediterrani occidental. Monografies Badalonines 9: 217-223. Badalona, Museu de Badalona.

Nolla, J.M. (2008): "La producción de les àmfores tarraconenses a la Catalunya septentrional", en $L a$ producción $i$ el comerç de les àmfores de la Provincia Hispania Tarraconensis. Homenatge a Ricard Pascual i Guasch: 163-175. Barcelona, Museu d'Arqueologia de Catalunya.

Nolla, J.M. y Nieto, F.J. (1989): “La importación de ánforas romanas en Cataluña durante el periodo tardo-republicano“, en M. Lenoird, D. Manacorda y C. Panella (eds.), Amphores romaines et Histoire Économique. Dix ans de recherches. Collection de l'École Francaise de Rome 114: 367-391. Paris Roma, École Francaise de Rome

Nolla, J.M. y Solías, J.M. (1988): "L'àmfora Tarraconense 1. Característiques, procedència, àrees de producció, cronologia“. Butlletí Arqueològic de Tarragona $1984-85$ : 107-144.

Olesti, O. (1993): "Les actuacions pompeianes a la Catalunya central; reorganització del territori i fundació de noves ciutats", en Actas del XIV Congreso Internacional de Arqueología Clásica. La ciudad en el mundo romano, vol. II: 316-317. Barcelona, Consejo Superior de Investigaciones Científicas.

Olesti, O. (1997): "Els primers productors d'àmfores vinícoles al Maresme (s. I aC)“, en Annals de l'Institut d'Estudis Gironins (Hispània i Roma. D'August a Carlemany. Congrès d'homenatge al Dr. Pere de Palol): 425-448. Girona, Institut d'Estudis Gironins. 
Olesti, O. (1998): "Els inicis de la producción vinícola a Catalunya: el paper del món indígena", en El vi a l'Antiguitat, economia, producció i comerç al Mediterrani Occidental. Monografies Badalonines 14: 246-257. Badalona, Museu de Badalona.

Panella, Cl. (1973): “Appunti su un gruppo di anfore della prima, media e tarda età Imperiale", en Ostia III: Le terme del Nuotatore: Scavi degli ambienti III, VI, VII. Scavo dell'ambiente $V$ et di un saggio dell'area SO. Studi Miscellanei 21: 460-633. Roma, L'Erma di Bretschneider.

Panosa, M.I. (2002): La història antiga de Montmeló (Vallés Oriental) a partir de la Col-lecció Cantarell. Montmeló, Museu Municipal de Montmeló.

Pascual, R. (1981): "Exploración submarina entre Llavaneres i Mataró". Ampurias 43: 217-251.

Pascual, R. (1991): Índex d'estampilles sobre àmfores catalanes. Cuadernos de Arqueología 5. Barcelona, L'Estaquirot.

Pena, M.J. (1982): “Ampurias romana a través de su epigrafía”. Cypsela 4: 173-178.

Pena, M.J. (1998): "Productores i comerciantes de vino layetano", en $2 n$ Col-loqui Internacional d'Arqueologia Romana. El vi a l'Antiguitat, economia, producció i comerç al Mediterrani Occidental. Monografies Badalonines 14: 305-318. Badalona, Museu de Badalona.

Pena, M.J. y Barreda, A., (1997): "Productores de vino del nordeste de la Tarraconense. Estudio de algunos nomina sobre ánforas Laietana 1 (= Tarraconense 1)". Faventia 19/2: 51-73.

Pera, J. (1994): “Una interessant marca d'àmfora Dressel 1 laietana procedent de Santa Eulàlia de Ronçana (Vallès Oriental)". Laietània 9: 373-374.

Revilla, V. (1993): Producción cerámica y economía rural en el Bajo Ebro en época romana. El alfar de l'Aumedina. Tivissa (Tarragona). Colección Instrumenta 1. Barcelona, Universitat de Barcelona.

Revilla, V. (1994): "El alfar romano de Tomoví. Producción anfórica y agricultura en el área de $T a$ rraco". Butlletí Arqueològic época V núm. 16: 111-128.

Revilla, V. (1995): Producción cerámica, viticultura y propiedad rural en Hispania Tarraconensis (siglos I
a.C.-III d.C.). Cuadernos de Arqueología 8. Barcelona, L'Estaquirot.

Revilla, V. (2004): “Ánforas y epigrafía anfórica en Hispania Tarraconenses”, en J. Remesal (ed.), Epigrafía anfórica: 159-196. Barcelona, Universitat de Barcelona.

Roddaz, J.-M. (1988): “Guerres civiles et romanisation dans la vallée de l'Ebre", en Hommage à Robert Etienne. París, Diffussion De Boccard.

Ruíz de Arbulo, J. (2002): "La fundación de la colonia Tárraco y los estandartes de César", en J.L. Jiménez y A. Ribera (eds.), Valencia y las primeras ciudades romanas de Hispania: 137-156. Valencia, Ayuntamiento de Valencia.

Solier, Y. (1981): "Les épaves de Gruissan". Archaeonautica 3: 8-264.

Tchernia, A. (1986): Le vin de l'Italie romaine. Essai d'histoire économique d'après les amphores. Roma, Ecole Française de Rome.

Tremoleda, J. (1998): “Pvblivs Vsvlenvs Veiento, un magistrat narbonès amb propietats al nord de la Tarraconense", en Congrés Internacional d'Arqueologia de Puigcerdà 11: 231-241. Moià, Institut d'Estudis Ceretans - Gràfiques ISTER de Moià.

Tremoleda, J. (2008): "Les instal lacions productives d'àmfores tarraconenses", en La producción i el comerç de les àmfores de la Provincia Hispania Tarraconensis. Homenatge a Ricard Pascual i Guasch: 113-150. Barcelona, Museu d'Arqueologia de Catalunya.

Vilà, M.V. (1996): “Àmfora amb inscripción llatina i grafit ibèric”. Pyrenae 27: 295-299.

Vilà, M.V.; Genera, M.; Huntingford, E. y Molas, M.D. (1978): "Aportaciones al conocimiento de la Antigua Blandae. Estudio de una habitación romana”. Pyrenae 13-14: 211-251.

Villaronga, L. (1979): Numismática Antigua de Hispania. Iniciación a su estudio. Barcelona, Ed. CYMYS.

Zaccaria, C. (1989): "Per una prosopografia dei personaggi menzionati sui bolli delle anfore romane dell'Italia nordorientale", en Amphores romaines et histoire économique: dix ans de recherches. Collection de l'École Francaise de Rome 114: 469-488. Paris - Roma, École Française de Rome. 